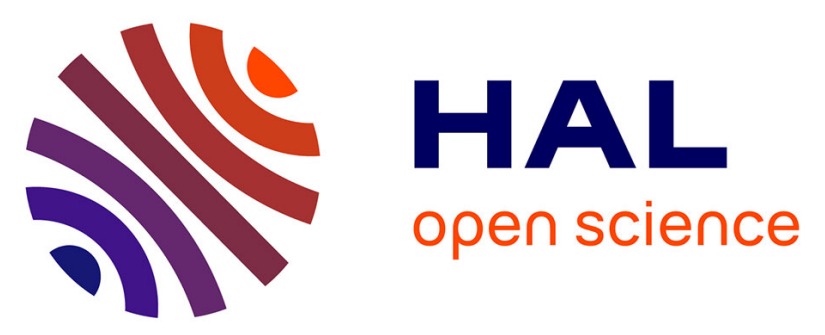

\title{
The Early Andean subduction system as an analogue to island arcs: evidence from across-arc geochemical variations in northern Chile
}

Pablo Rossel, Veronica Oliveros, Mihai N. Ducea, Reynaldo Charrier, Stéphane Scaillet, Leonardo Retamal, Oscar Figueroa

\section{To cite this version:}

Pablo Rossel, Veronica Oliveros, Mihai N. Ducea, Reynaldo Charrier, Stéphane Scaillet, et al.. The Early Andean subduction system as an analogue to island arcs: evidence from across-arc geochemical variations in northern Chile. Lithos, 2013, 179, pp.211-230. 10.1016/j.lithos.2013.08.014 . insu00857256

\section{HAL Id: insu-00857256 \\ https://hal-insu.archives-ouvertes.fr/insu-00857256}

Submitted on 4 Sep 2013

HAL is a multi-disciplinary open access archive for the deposit and dissemination of scientific research documents, whether they are published or not. The documents may come from teaching and research institutions in France or abroad, or from public or private research centers.
L'archive ouverte pluridisciplinaire HAL, est destinée au dépôt et à la diffusion de documents scientifiques de niveau recherche, publiés ou non, émanant des établissements d'enseignement et de recherche français ou étrangers, des laboratoires publics ou privés. 


\title{
The Early Andean subduction system as an analogue to island arcs: evidence from across-arc geochemical variations in northern Chile.
}

\author{
Pablo Rossel $^{\mathrm{a}}$, Verónica Oliveros ${ }^{\mathrm{a}^{*}}$, Mihai N. Ducea ${ }^{\mathrm{b}, \mathrm{e}}$, Reynaldo Charrier ${ }^{\mathrm{c}, \mathrm{d}}$, Stéphane \\ Scaillet $^{\mathrm{f}}$, Leonardo Retamal ${ }^{\mathrm{g}}$, Oscar Figueroa ${ }^{\mathrm{a}}$. \\ ${ }^{a}$ Departamento Ciencias de la Tierra, Universidad de Concepción, Casilla 160-C, Concepción, Chile. \\ ${ }^{\mathrm{b}}$ Department of Geosciences, University of Arizona, Tucson, AZ 85721, USA \\ ${ }^{c}$ Escuela Ciencias de la Tierra, Universidad Andres Bello, Campus República, Santiago. \\ ${ }^{\mathrm{d} D e p a r t a m e n t o ~ d e ~ G e o l o g i ́ a, ~ U n i v e r s i d a d ~ d e ~ C h i l e, ~ P l a z a ~ E r c i l l a ~ 803, ~ S a n t i a g o, ~ C h i l e . ~}$ \\ ${ }^{\text {e}}$ Universitatea Bucuresti, Facultatea de Geologie Geofizica, Strada N. Balcescu Nr 1, Bucuresti, Romania \\ ${ }^{\mathrm{f}}$ Institut des Sciences de la Terre d'Orléans (ISTO), 1A rue de la Férolerie, 45071 Orléans Cedex 2, France \\ ${ }^{\mathrm{g}}$ Minera Escondida, Avenida de la Minería N501, Antofagasta.
}

*Corresponding author. Email: voliveros@udec.cl

Phone number: 56-41-2203070

\section{Abstract}

The Upper Jurassic volcanic rocks of the Pre-Cordillera and High Andes of northern Chile $\left(26-31^{\circ} \mathrm{S}\right)$ represent a back-arc magmatic chain that developed during the early Andean subduction stage. After the Callovian, the dominant marine environment of this back-arc basin became continental and restricted volume of basaltic to riolitic rocks erupted along two belts, parallel to the coeval arc. The western belt comprises the Picudo and Algarrobal formations, whereas the eastern belt is represented by the Lagunillas Formation and the Quebrada Vicuñita Beds. New major and trace elements data, along with $\mathrm{Nd}-\mathrm{Sr}$ and $\mathrm{Pb}$ isotope ratios are presented for these volcanic belts and compared to the geochemical features of the Jurassic and Early Cretaceous arc magmatism. Ar-Ar and U-Pb ages constrain the time span for the volcanism between $163.9 \pm 1.4$ and $148.9 \pm 1.2 \mathrm{Ma}$. Rocks belonging to the western belt, closer to the arc front, have steep multielement patterns, low concentrations of HREE, suggesting the presence of garnet in the source, and a more radiogenic isotopic composition than the arc magmatism. Parental magmas of these back-arc lavas would have been generated through melting of a depleted mantle, although less depleted than the sub-arc mantle, and interacted with minor amounts of Paleozoic crust. The geochemical composition of the rocks belonging to the eastern belt is more heterogeneous and suggests involvement of different magmatic sources, including shallow depleted asthenosphere as well as an OIB-type mantle within the wedge.

In spite the fact that the Jurassic Andean arc was built over a continental plate, the architecture of the volcanic chains and geochemical variations observed among the arc and back-arc rocks in northern Chile resemble those in modern island arcs, and thus support the hypothesis that early Andean subduction developed under extensional tectonic conditions 


\section{Introduction}

The onset of Andean Tectonic Cycle took place roughly at $200 \mathrm{Ma}$, after a stage of extension and rifting of the western margin of the South American continental plate due to arrested or very slow/oblique subduction during Late Permian to Early Jurassic (Charrier, 1979; Mpodozis and Ramos, 1989, 2008; Vásquez et al., 2011). The voluminous magmatism developed during the Jurassic to Early Cretaceous in the Coastal Cordillera of southern Peru and northern-central Chile, was produced during multiestage tectonic evolution, with episodes of transtension and extension, expressed in important oblique and normal components observed in rocks associated to the Atacama Fault System (Grocott and Taylor, 2002; Pichowiack, 1994; Scheuber and González, 1999). The oblique subduction of the cold and dense Phoenix plate under the continent resulted in a roll-back of the oceanic plate, retreat of the trench, progressive thinning of the continental crust and the subsequent development of a north-south trending paleogeography (Grocott and Taylor, 2002; Charrier et al., 2007 and references therein). This paleogeographic configuration was characterized by intensive volcanism and plutonism in the arc region (the present day Coastal Cordillera from $17^{\circ}$ to $35^{\circ} \mathrm{S}$ ), and along-strike back-arc extension to the east (Mpodozis and Ramos, 1989; Vicente et al., 1982; Amilibia et al., 2008; Martinez et al., 2012). The magmatism exposed in the Coastal Cordillera has been widely studied in the past decades, establishing the fluid-induced melting of the upper mantle as the main source of arc magmas with little or no crustal contribution (Kramer et al., 2005; Lucassen et al., 2006; Oliveros et al., 2006, 2007; Palacios, 1978; Vergara et al., 1995). However, the volcanism in the back-arc domain, represented between $26^{\circ}$ and $31^{\circ} \mathrm{S}$ by the Quebrada Vicuñitas Beds and the Lagunillas, Picudo and Algarrobal formations, is still a relatively unexplored subject. Two scenarios have been proposed for this volcanism: a) the development of an outer arc (Ramos and Aleman, 2000) or b) an extensional back-arc chain (Charrier et al., 2007). Both hypotheses rely on very scarce geochemical and petrological data.

In this work, we present the first extensive data base of geochemical, isotopic and geochronological (U-Pb and Ar-Ar) analysis for the unstudied lavas of the back-arc domain, complemented with geochemical data of the Agua Salada Volcanic Complex (ASVC), which is one of the units of the Mezosoic arc that remained unstudied so far. The primary goals of this paper are i) to characterize, based on its petrology and geochemistry, the volcanism developed in the back-arc region of northern Chile during the Late Jurassic, ii) to unravel its petrogenetical conditions and magmatic sources, iii) to establish its timing 
and relationships with the Jurassic-Early Cretaceous arc magmatism in the western margin of Gondwana.

\section{Geological background}

Jurassic and Early Cretaceous arc magmatism is well exposed in the present-day Coastal Cordillera of Peru and Chile, between $17^{\circ}$ and $35^{\circ} \mathrm{S}$. To the East of the arc system, extensive back-arc basins developed during the same period, leading to the deposition of sedimentary units now cropping out in the Pre-Cordillera and High Andes (Fig. 1). The arc was constructed by voluminous magmatism producing up to 7,000 m-thick volcanic sequences with minor sedimentary intercalations, represented by the La Negra Formation and its equivalents in northern Chile (Camaraca and Oficina Viz formations) and southern Peru (Chocolate Formation), the Punta del Cobre Formation and the Agua Salada Volcanic Complex (Buchelt and Tellez, 1988; Emparán in press; Emparan and Pineda, 2000; Jenks, 1948; Marschik and Fontboté, 2001; Muñoz et al., 1988; SERNAGEOMIN, 2003), along with huge batholithic bodies that range in composition from gabbro to granodiorite (Arévalo and Welkner, 2008; Creixell et al., 2009; Emparan in press; Emparan and Pineda, 2000; Rivano and Sepúlveda, 1986; Welkner et al., 2006). This volcanism is remarkably homogeneous in composition and petrological characteristics. Lava flows of basaltic andesite composition are dominant, whereas more acidic or pryroclastic rocks are volumetrically restricted. Both plutonic and volcanic units have calc-alkaline affinities and are considered the products of subduction-related magmatism (Kramer et al., 2005; Lucassen et al., 2006; Oliveros et al., 2006, 2007; Palacios, 1978; Vergara et al., 1995).

The back-arc region developed in response to the progressive thinning of the continental crust associated to extension (Charrier et al., 2007). Up to 4,000 meters of marine and continental sedimentary rocks were deposited during the Jurassic and Early Cretaceous (Mpodozis and Ramos, 1989). At least two transgression-regression cycles are recorded in the sedimentary units of the back-arc Tarapacá Basin in northern Chile as well as in the Neuquén basin which is located further south in western Argentina (Hallam, 1991; Vicente et al., 2006) (Fig. 1b). The marine units representing the earlier transgressive phase in northern Chile $\left(26^{\circ}\right.$ to $31^{\circ} \mathrm{S}$, Fig. 1$)$ are the Asientos, Lautaro and Tres Cruces formations, of Sinemurian to Calovian(?) age (Cornejo et al., 1998; Harrington, 1961; Iriarte, 1999, 1995; Jensen, 1976; Moscoso et al., 2010; Mpodozis and Cornejo,1986; Nasi et al., 1986; Soffia, 1989). The first regressive phase (Late Jurassic) led to the emersion of the back-arc and subsequent deposition of red volcano-sedimentary sequences. In general, these units consist of clastic sediments that grade from sandy to coarse conglomerates, with intercalations of basic to andesitic material, and minor interbedded acid pyroclastic rocks (Jensen, 1976; Oliveros et al. 2012; Ribba, 1986; Rossel, 2011; Soffia, 1989). The last marine transgression started in the Tithonian and is represented by the Chanarcillo Group 
and the Pedernales and Río Tascadero formations, in the Tarapacá basin (Vicente, 2006) and by the Lo Valdés and Vaca Muerta formations in the Neuquén basin, further south (Hallam et al., 1986; Howell et al., 2005).

Among the Upper Jurassic back-arc geological units that have volcanic rocks interbedded are the Quebrada Vicuñitas Beds (QVB) and the Lagunillas (LF), Picudo (PF) and Algarrobal (AF) formations (Charrier et al., 2007). They are exposed in the PreCordillera and High Andes between $26^{\circ}$ y $31^{\circ} \mathrm{S}$, as two belts parallel to the arc outcrops (Fig. 1a). Why this magmatism is volumetrically restricted and whether the volcanic rocks are the product of back-arc volcanism occurred during the first regressive phase of the basin or they represent another subduction-related process remain unsolved issues due to the lack of geochemical, petrological and geochronological data. Generalized description of each unit is listed in Table 1.

\section{Analytical Methods}

Forty samples of the back-arc Upper Jurassic volcano-sedimentary units were collected for petrographical, geochemical and geochronological analysis: thirty two lavas, seven tuffs and one volcanic breccia. Aditionally, five samples from the Agua Salada Volcanic Complex and one sample from the La Negra Formation, as representative of the coeval arc volcanism, were collected for geochemical analysis. The main petrographic characteristics of the selected samples are listed in Table 2.

\subsection{Whole rock analysis}

Major and trace element concentrations were determined using standard XRF and ICP-MS techniques at the Washington State University and the Chilean Mining and Geological Survey (SERNAGEOMIN) laboratories. Whole-rock trace elements were measured in solution using a Thermo Element X-Series II single collector ICP-MS at the University of Arizona. Approximately $5 \mathrm{mg}$ of sample were dissolved in about $7 \mathrm{ml}$ of concentrated $\mathrm{HF}-\mathrm{HNO}_{3}$ mixtures, dried down and redissolved in a mild $1 \%$ nitric acid before being analyzed. Several 1-10 ppm internal standards were used for different elements. Columbia River Basalt material standard material was used as an external standard. Analysis routines involved 30 individual measurements of isotopes free of interferences. Typical analytical errors are 3-5\% of the reported values. In addition, $\mathrm{Rb}, \mathrm{Sr}$, $\mathrm{Sm}$ and $\mathrm{Nd}$ were measured by isotope dilution on separate aliquots (see below) for isotope age correction. All samples had consistent trace elemental results between ICP-MS and isotope dilution TIMS data, evidently with the much higher precision of the isotope dilution technique. 
$\mathrm{Rb}, \mathrm{Sr}, \mathrm{Sm}$, and $\mathrm{Nd}$ trace elemental and $\mathrm{Sr}, \mathrm{Nd}, \mathrm{Pb}$ isotopic analyses of thirty seven whole-rock samples were performed for this study at the University of Arizona. The isotopic ratios of ${ }^{87} \mathrm{Sr} /{ }^{86} \mathrm{Sr},{ }^{143} \mathrm{Nd} /{ }^{144} \mathrm{Nd}$, and the trace element concentrations of $\mathrm{Rb}, \mathrm{Sr}, \mathrm{Sm}$, and $\mathrm{Nd}$ were measured by thermal ionization mass spectrometry on whole rock samples. Rock samples were crushed to a fine powder using a pulverizer or a mortar and pestle. Rock powders were put in large Savillex vials and dissolved in mixtures of hot concentrated HF-HNO3 or alternatively, mixtures of cold concentrated $\mathrm{HF}-\mathrm{HClO}_{4}$. The dissolved samples were spiked with the Caltech $\mathrm{Rb}, \mathrm{Sr}$, and mixed Sm-Nd spikes (Ducea and Saleeby, 1998; Wasserburg et al., 1981) after dissolution. Rb, Sr, and the bulk of the REEs were separated in cation columns containing AG50W-X4 resin, using $1 \mathrm{~N}$ to $4 \mathrm{~N} \mathrm{HCl}$. Separation of Sm and Nd was achieved in anion column containing LN Spec resin, using $0.1 \mathrm{~N}$ to $2.5 \mathrm{~N} \mathrm{HCl}$. $\mathrm{Rb}$ was loaded onto single Re filaments using silica gel and $\mathrm{H}_{3} \mathrm{PO}_{4} . \mathrm{Sr}$ was loaded onto single Ta filaments with $\mathrm{Ta}_{2} \mathrm{O}_{5}$ powder. $\mathrm{Sm}$ and $\mathrm{Nd}$ were loaded onto single Re filaments using platinized carbon, and resin beads, respectively.

Mass spectrometric analyses were carried out at the University of Arizona on an automated VG Sector multicollector instrument fitted with adjustable $10^{11} \Omega$ Faraday collectors and a Daly photomultiplier (Otamendi et al., 2009). Concentrations of Rb, $\mathrm{Sr}$, $\mathrm{Sm}, \mathrm{Nd}$ were determined by isotope dilution, with isotopic compositions determined on the same spiked runs. An off-line manipulation programs was used for isotope dilution calculations. Typical runs consisted of acquisition of 100 isotopic ratios. The mean result of ten analyses of the standard NRbAAA performed during the course of this study is: ${ }^{85} \mathrm{Rb} /{ }^{87} \mathrm{Rb}=2.61179 \pm 20$. Fifteen analyses of standard Sr987 yielded mean ratios of: ${ }^{87} \mathrm{Sr} /{ }^{86} \mathrm{Sr}=0.710255 \pm 7$ and ${ }^{84} \mathrm{Sr} /{ }^{86} \mathrm{Sr}=0.056326 \pm 12$. The mean results of five analyses of the standard $\mathrm{nSm} \beta$ performed during the course of this study are: ${ }^{148} \mathrm{Sm} /{ }^{147} \mathrm{Sm}=$ $0.74880 \pm 21$, and ${ }^{148} \mathrm{Sm} /{ }^{152} \mathrm{Sm}=0.42110 \pm 6$. Fifteen measurements of the LaJolla Nd standard were performed during the course of this study. The standard runs yielded the following isotopic ratios: ${ }^{142} \mathrm{Nd} /{ }^{144} \mathrm{Nd}=1.14174 \pm 2,{ }^{143} \mathrm{Nd} /{ }^{144} \mathrm{Nd}=0.5118488 \pm 2$, ${ }^{145} \mathrm{Nd} /{ }^{144} \mathrm{Nd}=0.348390 \pm 2$, and ${ }^{150} \mathrm{Nd} /{ }^{144} \mathrm{Nd}=0.23638 \pm 2$. The Sr isotopic ratios of standards and samples were normalized to ${ }^{86} \mathrm{Sr} /{ }^{88} \mathrm{Sr}=0.1194$, whereas the Nd isotopic ratios were normalized to ${ }^{146} \mathrm{Nd} /{ }^{144} \mathrm{Nd}=0.7219$. The estimated analytical $\pm 2 \sigma$ uncertainties for samples analyzed in this study are: ${ }^{87} \mathrm{Rb} /{ }^{86} \mathrm{Sr}=0.15 \%,{ }^{87} \mathrm{Sr} /{ }^{86} \mathrm{Sr}=0.0011 \%,{ }^{147} \mathrm{Sm} /{ }^{144} \mathrm{Nd}$ $=0.2 \%$, and ${ }^{143} \mathrm{Nd} /{ }^{144} \mathrm{Nd}=0.0010 \%$. Procedural blanks averaged from five determinations were: Rb-7 pg, Sr-110 pg, Sm- 2.7 pg, and Nd - 5.3 pg.

Washes from the cation column separation were used for separating $\mathrm{Pb}$ in $\mathrm{Sr}-\mathrm{Spec}$ resin (Eichrom, Darien, IL) columns by using protocol developed at the University of Arizona. Samples are being loaded in $8 \mathrm{M} \mathrm{HNO}_{3}$ in the $\mathrm{Sr}$ spec columns. $\mathrm{Pb}$ elution is achieved via $8 \mathrm{M} \mathrm{HCl}$. Pb isotope analysis was conducted on a $\mathrm{GV}$ Instruments (Hudson, $\mathrm{NH})$ multicollector inductively coupled plasma mass spectrometer (MC-ICP-MS) at the 
University of Arizona (Drew et al., 2009). Samples were introduced into the instrument by free aspiration with a low-flow concentric nebulizer into a water-cooled chamber. A blank, consisting of $2 \% \mathrm{HNO}_{3}$, was run before each sample. Before analysis, all samples were spiked with a $\mathrm{Tl}$ solution to achieve $\mathrm{a} \mathrm{Pb} / \mathrm{Tl}$ ratio of $\approx 10$. Throughout the experiment, the standard National Bureau of Standards (NBS)-981 was run to monitor the stability of the instrument.

All results were $\mathrm{Hg}$-corrected and empirically normalized to $\mathrm{Tl}$ by using an exponential law correction. To correct for machine and interlaboratory bias, all results were normalized to values reported by Galer and Abouchami (2004) for the National Bureau of Standards (NBS)-981 standard $\left({ }^{206} \mathrm{~Pb} /{ }^{204} \mathrm{~Pb}=16.9405,{ }^{207} \mathrm{~Pb} /{ }^{204} \mathrm{~Pb}=15.4963\right.$, and ${ }^{208} \mathrm{~Pb} /{ }^{204} \mathrm{~Pb}=36.7219$ ). Internal error reflects the reproducibility of the measurements on individual samples, whereas external errors are derived from long-term reproducibility of NBS-981 Pb standard and result in part from the mass bias effects within the instrument. In all cases, external error exceeds the internal errors and is reported below. External errors associated with each $\mathrm{Pb}$ isotopic ratio are as follows: ${ }^{206} \mathrm{~Pb} /{ }^{204} \mathrm{~Pb}=0.028 \%,{ }^{207} \mathrm{~Pb} /{ }^{204} \mathrm{~Pb}=$ $0.028 \%$, and ${ }^{208} \mathrm{~Pb} /{ }^{204} \mathrm{~Pb}=0.031 \%$.

\subsection{U-Pb geochronology of igneous zircons}

Zircons were extracted from two tuffs (PR-11-143, PR-11-150) and one dacite (PR11-193) by crushing, milling, gravitational separation and heavy liquids treatment. At least 50 crystals were randomly selected (regardless their size, form or color) using a stereomicroscope and then mounted in $25 \mathrm{~mm}$ epoxy and polished.

$\mathrm{U}-\mathrm{Pb}$ geochronology of zircons was conducted by LA-MC-ICP-MS at the Arizona LaserChron Center (Gehrels et al., 2008). The analyses involve ablation of zircon with a New Wave/Lambda Physik DUV193 Excimer laser (operating at a wavelength of $193 \mathrm{~nm}$ ) using a spot diameter of 25 or $35 \mu \mathrm{m}$. The ablated material is carried with helium gas into the plasma source of a GV Instruments Isoprobe, which is equipped with a flight tube of sufficient width that $\mathrm{U}, \mathrm{Th}$, and $\mathrm{Pb}$ isotopes are measured simultaneously. All measurements are made in static mode, using Faraday detectors for ${ }^{238} \mathrm{U}$ and ${ }^{232} \mathrm{Th}$, an ioncounting channel for ${ }^{204} \mathrm{~Pb}$, and either Faraday collectors or ion counting channels for ${ }^{208-}$ ${ }^{206} \mathrm{~Pb}$. Ion yields are $\sim 1 \mathrm{mV} \mathrm{ppm}^{-1}$. Each analysis consists of one 20 s-integration on peaks with the laser off (for backgrounds), twenty $1 \mathrm{~s}$-integrations with the laser firing, and a $30 \mathrm{~s}$ delay to purge the previous sample and to prepare for the next analysis. The ablation pit is $\sim 15 \mu \mathrm{m}$ in depth.

For each analysis, the errors in determining ${ }^{206} \mathrm{~Pb} /{ }^{238} \mathrm{U}$ and ${ }^{206} \mathrm{~Pb} /{ }^{204} \mathrm{~Pb}$ result in a measurement error of $\sim 1 \%$ (at $2 \mathrm{~s}$ level) in the ${ }^{206} \mathrm{~Pb} /{ }^{238} \mathrm{U}$ age. The errors in measurement of 
${ }^{206} \mathrm{~Pb} /{ }^{207} \mathrm{~Pb}$ and ${ }^{206} \mathrm{~Pb} /{ }^{204} \mathrm{~Pb}$ also result in $\sim 1 \%$ (2s) uncertainty in age for grains that are $>1.0$ $\mathrm{Ga}$, but are substantially larger for younger grains due to low intensity of the ${ }^{207} \mathrm{~Pb}$ signal. For most analyses, the crossover in precision of ${ }^{206} \mathrm{~Pb} /{ }^{238} \mathrm{U}$ and ${ }^{206} \mathrm{~Pb} /{ }^{207} \mathrm{~Pb}$ ages occurs at $\sim 1.0 \mathrm{Ga}$. Common $\mathrm{Pb}$ correction is accomplished by using the measured ${ }^{204} \mathrm{~Pb}$ and assuming an initial $\mathrm{Pb}$ composition from Stacey and Kramers (1975) (with uncertainties of 1.0 for ${ }^{206} \mathrm{~Pb} /{ }^{204} \mathrm{~Pb}$ and 0.3 for ${ }^{207} \mathrm{~Pb} /{ }^{204} \mathrm{~Pb}$ ). The measurement of ${ }^{204} \mathrm{~Pb}$ is unaffected by the presence of ${ }^{204} \mathrm{Hg}$ because backgrounds are measured on peaks (thereby subtracting any background ${ }^{204} \mathrm{Hg}$ and ${ }^{204} \mathrm{~Pb}$ ), and because very little $\mathrm{Hg}$ is present in the argon gas. Interelement fractionation of $\mathrm{Pb} / \mathrm{U}$ is generally $\sim 20 \%$, whereas fractionation of $\mathrm{Pb}$ isotopes is generally $<2 \%$. In-run analysis of fragments of a large Sri Lanka zircon crystal (generally every fifth measurement) with known age of $564 \pm 4 \mathrm{Ma}$ (2s error) is used to correct for this fractionation (see Gehrels et al., 2008). The uncertainty resulting from the calibration correction is generally $\sim 1 \%$ (2s) for both ${ }^{206} \mathrm{~Pb} /{ }^{207} \mathrm{~Pb}$ and ${ }^{206} \mathrm{~Pb} /{ }^{238} \mathrm{U}$ ages.

The reported ages are determined from the weighted mean of the ${ }^{206} \mathrm{~Pb} /{ }^{238} \mathrm{U}$ ages of the concordant and overlapping analyses (Ludwig, 2003). The reported uncertainty (labeled "mean") is based on the scatter and precision of the set of ${ }^{206} \mathrm{~Pb} /{ }^{238} \mathrm{U}$ or ${ }^{206} \mathrm{~Pb} /{ }^{207} \mathrm{~Pb}$ ages, weighted according to their measurement errors (shown at 1s). The systematic error, which includes contributions from the standard calibration, age of the calibration standard, composition of common $\mathrm{Pb}$ and $\mathrm{U}$ decay constants, is generally $\sim 1-2 \%$ (2s).

\subsection{Ar-Ar geochronology}

Four samples were selected for Ar-Ar geochronological analyses of hornblende grains: a basaltic lava flow of the Quebrada Vicuñita Beds (PR-09-19), a volcanic breccia of the Picudo Formation (PR-09-07), a dacitic tuff assigned to the Lagunillas Formation (PR-10-98) and a dacitic breccia assigned to the Algarrobal Formation (PR-11-161). The separates of fresh hornblende were analyzed by $\mathrm{CO}_{2}$ laser step heating in the Laboratoire des Sciences du Climat et de l'Environnement (Gif-sur-Yvette, France). Mineral separation was carried out using a Frantz magnetic separator and finally by careful handpicking under a binocular microscope. Separated grains $(200-315 \mu \mathrm{m})$ were then rinsed in deionised water, acetone, alcohol and deionised water again. The mineral grains were loaded into two $4 \mathrm{~mm}$ i.d. holes on an aluminium tray (with the mineral ACR-2 as a flux monitor in two adjacent holes), and were irradiated for 20 hours in the central position of the Osiris reactor (CEA-Saclay, France). Calibration of the neutron flux received by the samples yielded a $\mathrm{J}$ factor of $0.299( \pm 0.014) 10^{-2}$ (PR-09-07 and PR-09-19) and $0.332( \pm 0.008) 10^{-2}$ (PR-10-98 and PR-11-161). Upon reception and cooling after irradiation, the sanidine grains were transferred on a copper planchet machined with $4 \mathrm{~mm}$ i.d. holes, each loaded with about 10-15 mg (or 10-20 crystals) of material from each sample (eight holes for VAN 05021, five holes for VAN 05030). The grains from samples PR-09-07 and PR-09-19 were degassed in two consecutive steps with a $20 \mathrm{~W} \mathrm{CO}_{2}$ laser beam (first a low-temperature 
step, then a fusion step at about $20 \%$ of the full laser power). This was done in an attempt to optimize the resolution of discordant single grains (rather than analyzing them as a bulk population potentially masking inter-grain variations). Grains from the other two samples were degasses in several steps. The gases were purified by exposure to a GP50 nonevaporable getter pump equipped with a St 101 cartridge operated at $225^{\circ} \mathrm{C}$ and a titanium sublimation pump operated at room temperature, before admission into a GV 5400 mass spectrometer. Data reduction and analysis followed standard procedures (Scaillet, 2000; Scaillet et al., 2011).

\section{Petrographic characterization of the volcanism in the studied units}

The studied rocks are mainly lava flows of dominantly basic to intermediate composition and some pyroclastic deposits. The explosive rocks where only recognized in the westernmost units, the AF and PF (Fig. 1).

The lava flows have variable thicknesses between 1 to $10 \mathrm{~m}$; in some outcrops it is possible to differentiate the brecciated, the vesicular and the massive part of a single flow, but often secondary alteration processes have blurred the external textures of the rocks. Plagioclase and clinopyroxene are the most common crystalline components in the studied rocks, making up to $70 \%$ of the total volume. They occur as euhedral to subhedral phenocrysts and exhibit little evidence of alteration. Olivine occur as euhedral phenocrysts only in the lavas of PF and LF, being far more abundant in the latter, where they constitute up to $10 \%$ of the volume of the rock. Fe-Ti oxide occur as microcrystals in the matrix, commonly intergranular, and normally they constitute not more than the $5 \%$ of the volume of the rock. Minerals as orthopyroxene and amphibole are practically absent from the mineralogy of the studied lavas. Particularly, amphibole occur only in four of the collected samples: one basaltic adesite lava flow (PR-09-19), one andesitic breccia (PR-09-07) and two dacitic tuffs (PR-10-98 and PR-11-161). In such rocks they constitute no more than the $3 \%$ of the total volume, and occur as euhedral to subhedral crystals ranging from $1 \mathrm{~mm}$ (PR-09-19) to $15 \mathrm{~mm}$ (PR-09-07) in diameter. In sample PR-09-19, the amphibole crystals are located in areas of the matrix where the alteration is more penetrative.

All studied samples show variable degrees of alteration, but those collected from the central part of the lava flows are generally fresher, and thus preferred for geochemical analysis. The most common secondary mineral phases are: sericite (white mica) replacing plagioclase, chlorite as thin rimes in clinopyroxene phenocrysts and iddingsite (Fe-rich phylosillicate) completely replacing olivine. The groundmass is affected by different degrees of chloritization evidenced by a greenish-brownish color.

The pyroclastic rocks are crystalline and lithocrystalline tuffs ranging from few centimeters to more than 10 meters in thickness. The thicker pyroclastic deposits are within 
the PF and they contain elongated fiammes and fragments of pumicites immersed in a glassy matrix, with lesser amounts of fragmental quartz and plagioclase. Minor pyroclastic deposits are intercalated in the volcanic member of the LF, they are few centimeters in thickness and composed mainly by fragmental plagioclase, without quartz, immerse in a fine matrix. The small size of the crystals and the lack of lithic fragments in the pyroclastic rocks suggest that they are the distal portion of a fall deposit.

\section{Results}

\subsection{Major and trace element distribution}

The major, trace and rare earth (REE) elements abundances for the studied volcanic rocks are listed in Table 3.

\subsubsection{Alteration}

Calcite is a ubiquitous alteration mineral phase in the back-arc lavas, particularly within rocks of the LF and QBV; it occurs in fractures, amygdales or as cement in epiclastic sandstones interbeded with volcanic rocks. Remobilization of $\mathrm{CO}_{3}^{-2}$ from the back-arc marine sedimentary rocks that underlie the studied units is the likely process responsible for the carbonatic alteration. The high LOI percentage in some of the analyzed rocks is consistent with this scenario. In order to test the extent of element mobility in the analyzed samples, a comparison between the total alkalis versus silica (TAS) and $\mathrm{Zr} / \mathrm{Ti}$ versus $\mathrm{Nb} / \mathrm{Yb}$ classification diagrams was made (Fig. 2). Enrichment in alkalis is observed in rocks of all units but the QVB, and it is especially evident in the rocks of the LF. The classification in terms of the more immobile elements confirms the slight alkaline character of most units, again with the exception of the QVB (Fig 2b). Furthermore, even though the alkalis and $\mathrm{Al}_{2} \mathrm{O}_{3}$ have the highest dispersion within the major elements a trend of enrichment and depletion, respectively, is observed as $\mathrm{SiO}_{2}$, or differentiation, increases (Fig. 3). The major elements content in the analyzed rocks can be taken into account to identify magmatic processes if it is done with caution.

LILE show a greater dispersion than HFSE. Given the higher mobility of the former during the alteration processes, their usefulness in the interpretation of magmatic processes is limited, and discussion on the genesis and characteristics of the magmas must be performed mainly using the HFSE and REE. Particularly, sample PR-09-06 shows anomalous values of $\mathrm{Ca}, \mathrm{Sr}$ and $\mathrm{Zr}$ which can only be explained by posterior alteration processes, although it has a relatively low LOI of 2.07 and the petrographic analysis did not reveal a greater alteration degree than other studied rocks. Sample PR-11-188 has low 
values of $\mathrm{SiO}_{2}$, high concentrations of $\mathrm{CaO}$ and a LOI of 5.11, probably due to intense carbonatic alteration, and its results should be considered with caution.

\subsubsection{Major Elements}

The contents of $\mathrm{SiO}_{2}$ (on anhydrous basis) of the volcanic rocks vary significantly between $43.8 \%$ and $74.3 \%$. The rocks of the LF (excluding two crystalline tuffs) and QVB have the most restricted and lower $\mathrm{SiO}_{2}$ contents, 43.8 to $54.8 \%$ and 51.3 to $59.6 \%$, respectively (Fig 2a). Rocks of the PF and AF have a much broader compositional range, the latter being the most differentiated (Fig. 2a). The alkali content of the rocks range from 3 to $8 \mathrm{wt} \%$, and increases the higher the content of $\mathrm{SiO}_{2}$, reflecting their incompatibility in fractional crystallization processes. According to their $\mathrm{SiO}_{2}$ and $\mathrm{K}_{2} \mathrm{O}$ content the studied rocks have high-K calc-alkaline affinity. The wt $\%$ of $\mathrm{TiO}_{2}, \mathrm{MgO}$ and $\mathrm{FeO}_{\mathrm{t}}$ vary from 0.38 to $2.81,0.49$ to 11.24 and 0.73 to 12.40 , respectively, and samples of LF and QVB have the highest concentrations of these elements. Although the studied rocks form a relatively linear pattern of $\mathrm{FeO}_{\mathrm{t}}$ in relation to the content of $\mathrm{SiO}_{2}$, rocks of the QVB plot slightly above the trend line formed by the other units. The $\mathrm{Al}_{2} \mathrm{O}_{3}$ content ranges between 8.83 and $18.50 \mathrm{wt} \%$, decreasing progressively with increasing $\mathrm{SiO}_{2}$. Samples of the PF, and a subgroup of lavas from LF have exceptionally high $\mathrm{Al}_{2} \mathrm{O}_{3}$ between 16.40 and $18.50 \%$ escaping thus from the linear pattern formed by the other units (Fig. 3). The systematic decrease in the contents of $\mathrm{TiO}_{2}, \mathrm{FeO}, \mathrm{MgO}, \mathrm{Al}_{2} \mathrm{O}_{3}$ and $\mathrm{CaO}$ is compatible with progressive fractionation of Fe-Ti oxides, olivine and clinopyroxene, which is consistent with the observed mineralogy in the studied rocks.

\subsubsection{Trace and Rare Earth elements}

As observed in the multi-element diagrams (Fig. 4, 5) most of the studied samples show enrichment in LILE compared to HFSE, relative to primitive mantle concentrations. Plagioclase would have been extensively extracted out of the magma source only in the case of the AF and ASVC rocks, because the lavas of the other units do not exhibit Eu anomalies in the REE diagrams. High contents of $\mathrm{Pb}$ and $\mathrm{Nb}$-Ta troughs are observed in rocks of all units, only five samples of the LF exhibit a pattern lacking of $\mathrm{Nb}$-Ta anomaly. In particular, QVB rocks show flat REE patterns (Fig. 5), with $(\mathrm{La} / \mathrm{Yb})_{\mathrm{N}}$ ratios between approximate 3 and 11, relatively high content of $\mathrm{Yb}$ (approximate 13-22 times the chondrite), the highest concentrations of HFSE and the most pronounced $\mathrm{Nb}$ - $\mathrm{Ta}$ anomalies $\left(\mathrm{La}_{\mathrm{N}} / \mathrm{Nb}_{\mathrm{N}} \approx 2-11\right)$. QVB rocks have exceptionally high contents of $\mathrm{V}$, about 2 to 3 times higher than the rocks from other units. The rocks from PF and AF share similar characteristics in terms of their trace elements composition: steep multi-element and REE patterns, particularly for $\mathrm{PF},(\mathrm{La} / \mathrm{Yb})_{\mathrm{N}}$ ratios ranging from approximate 5 to 26 , lower $\mathrm{Yb}$ concentrations $(\approx 7$ to 22 times the chondrite) and $\mathrm{Nb}$-Ta anomalies somewhat less developed. In fact, the $(\mathrm{La} / \mathrm{Nb})_{\mathrm{N}}$ of $\mathrm{AF}(\approx 3-4)$ are similar to those of the Jurassic arc. 
The rocks of the LF have some very distinguishable features relative to other units and can be classified into two groups according to their geochemical properties. The first group has geochemical features typical of magmas associated with subduction, such LILE enrichment relative to HFSE, $\mathrm{Nb}$-Ta troughs $\left(\mathrm{La}_{\mathrm{N}} / \mathrm{Nb}_{\mathrm{N}}\right.$ between $\approx 2$ and 38$)$ and $\mathrm{Pb}$ enrichment. These rocks also have steep REE patterns with high variability of $\mathrm{Yb}_{\mathrm{N}}(\approx 4$ 24) and high $\mathrm{Al}_{2} \mathrm{O}_{3}$. Rocks belonging to the second group within this formation are the less differentiated among the studied units, with the lowest $\mathrm{SiO}_{2}$, and the highest $\mathrm{Ni}, \mathrm{Cr}, \mathrm{Ti}, \mathrm{Zr}$ and $\mathrm{Hf}$ contents. They have convex multi-element patterns, lack of $\mathrm{Nb}$-Ta troughs and no significant positive $\mathrm{Pb}$ anomalies. REE diagrams of these rocks show linear patterns (different from that observed in other units where the REE patterns are slightly flat in the HREE) with LREE enrichment respect to HREE, with $(\mathrm{La} / \mathrm{Yb})_{\mathrm{N}}$ ratios ranging between approximate 5 and 17 and $\mathrm{Yb}_{\mathrm{N}}$ concentrations of about 6 to 11 times the chondrite.

Another important feature observed in the REE patterns of the studied rocks, with the exception of QVB and AF, is the low contents of HREE, especially $\mathrm{Yb}$ and $\mathrm{Y}$. This could be indicative of the presence of small amounts of garnet in the source of the magmas.

\subsection{Isotopic composition}

The $\mathrm{Sr}-\mathrm{Nd}-\mathrm{Pb}$ isotope composition of the studied samples are listed in Table 4. Sr and $\mathrm{Nd}$ were recalculated to an initial ratio at $150 \mathrm{Ma}$. These results constitute the first database for Jurassic rocks in the Chilean Precordillera and Principal Cordillera.

${ }^{87} \mathrm{Sr} /{ }^{86} \mathrm{Sr}$ values for rocks of the back-arc domain range from 0.7006 to 0.7058 . In general, the $\mathrm{PF}$ and $\mathrm{AF}$ rocks, which were are located closer to the arc, are less radiogenic than those of LF (Fig. 6). The ${ }^{87} \mathrm{Sr} /{ }^{86} \mathrm{Sr}$ of the QVB and LF lavas are the highest among the back-arc rocks, making these samples to escape from the "mantle array" trend in the $\mathrm{Sr}-\mathrm{Nd}$ diagram (Fig. 6). Since the QVB likely erupted in a subaquatic environment (Table 1), the radiogenic Sr could be due to seawater alteration. The high ${ }^{87} \mathrm{Sr} /{ }^{86} \mathrm{Sr}$ of the LF rocks could be due to the intense carbonatic alteration they exhibit.

The ${ }^{143} \mathrm{Nd} /{ }^{144} \mathrm{Nd}$ range between 0.5124 and $0.5129\left(\varepsilon \mathrm{Nd}_{\mathrm{i}}\right.$ between 6.0 and 0.2$)$; rocks from the QVB have the most radiogenic values $\left(\varepsilon \mathrm{Nd}_{\mathrm{i}}\right.$ mostly between 3.0 and 6.0$)$, whereas rocks of the $\mathrm{PF}$ and $\mathrm{AF}$ have variable values of $\varepsilon \mathrm{Nd}_{\mathrm{i}}$ ranging from 3.8 a 0.2. Finally, the two groups of rocks of the LF have also distinct Nd isotopic composition, those samples with $\mathrm{Nb}$-Ta anomaly, excluding the crystalline tuffs, are most radiogenic $\left(\varepsilon \mathrm{Nd}_{\mathrm{i}}\right.$ between 1.2 to 6.3$)$ than those without this anomaly $\left(\varepsilon \mathrm{Nd}_{\mathrm{i}}\right.$ between 3.9 and 1.6).

The isotopic ratios of ${ }^{206} \mathrm{~Pb} /{ }^{204} \mathrm{~Pb},{ }^{207} \mathrm{~Pb} /{ }^{204} \mathrm{~Pb} \mathrm{y}{ }^{208} \mathrm{~Pb} /{ }^{204} \mathrm{~Pb}$ (Fig. 7) range between 18.40 and $19.43 ; 15.60$ and 15.88 and 38.43 to 40.15 respectively. Rocks of the PF and AF 
are the less radiogenic and plot close to the arc field, those of LF the most radiogenic, and those of QVB have intermediate values. The ${ }^{207} \mathrm{~Pb} /{ }^{204} \mathrm{~Pb}$ isotopic composition in rocks of the LF also varies depending on whether they have $\mathrm{Nb}-\mathrm{Ta}$ anomaly or not, being the samples of the latter group the more radiogenic (15.62 to 15.67).

The Sr-Nd isotopic values for the ASVC range between 0.7031-0.7044 and 0.51260.5127 respectively, very similar to those from the Jurassic Arc in Northern Chile, plotting inside the field defined by the $95 \%$ of published values for arc rocks (Fig. 6). The ${ }^{206} \mathrm{~Pb} /{ }^{204} \mathrm{~Pb},{ }^{207} \mathrm{~Pb} /{ }^{204} \mathrm{~Pb}$ y ${ }^{208} \mathrm{~Pb} /{ }^{204} \mathrm{~Pb}$ show range between 18.59 and $21.77,15.61$ and 16.00 and 38.49 to 42.53 , respectively, which are out from the range of arc rocks.

\subsection{Geochronology}

The results of Ar-Ar and U-Pb dating of volcanic rocks from the studied units are listed in detail in the electronic supplementary material. Additionally, the first $\mathrm{U}-\mathrm{Pb}$ age for the La Negra Formation (Jurassic arc) at this latitude is presented.

\subsubsection{Ar-Ar Geochronology}

Selected hornblende grains from a lithic juvenile clast in a volcanic breccia (PR-0907 ) at the base of the PF yielded a mean age of $163.2 \pm 1.4 \mathrm{Ma}$ (Fig. 8a), which was obtained from merging the the final fusion age of individual grains in a "pseudospectrum" gathering the ages of several crystals (Fig. 9, see Analytical techniques). The resulting age pattern is homogeneous, establishing a robust maximum age for this unit. Two samples of pyroclastic rocks of dacitic composition (PR-09-98 and PR-11-161) that had been previously assigned to the Jurassic back-arc sucessions (AF) Jensen, 1976; Martin et al., 1995) were selected for Ar-Ar analysis due to their distinct composition. Hornblende grains yielded a plateau age of $35.5 \pm 0.4 \mathrm{Ma}$ (Fig. 8b) and $72.6 \pm 0.7 \mathrm{Ma}$ (Fig. 8c), dismissing the possibility that these rocks belong to the Jurassic back-arc volcanism. Groundmass of a basaltic andesitic lava flow (sample PR-09-19, QVB), yielded a mean age of $72.9 \pm 0.3 \mathrm{Ma}$, which is hardly consistent with the Upper Jurassic age (based on its stratigraphic position) assigned to the rocks of this unit (Cornejo et al., 1998; Tomlinson et al., 1999). The age spectrum is complex however, possibly indicating late-stage or postclosure partial resetting of the primary (emplacement) age of the flow .

\subsubsection{U-Pb Geochronology}

Sample PR-11-193, a dacite located at the base of the volcanic deposits of LF (Fig. 1), yields an age of $148.9 \pm 2.1 \mathrm{Ma}$ (Fig. 9a), which is similar to the maximum depositional age of $150.8 \pm 4.0 \mathrm{Ma}$ estimated by Oliveros et al. (2012) in red sandstones of the LF cropping out further north (Fig. 1). Sample PR-11-150 was collected from an ignimbrite of 
the PF located ca. $100 \mathrm{~m}$ stratigraphically above the sample PR-09-07, and yields an age of $151.4 \pm 2.7 \mathrm{Ma}$ (Fig. 9b). Finally, a sample of crystalline tuff (PR-11-143), collected from the La Negra Formation (Fig. 1) near the contact with the Punta del Cobre Formation (pre Upper Valanginian age, Marschik and Fontboté, 2001), gave an age of 167.1 $\pm 1.8 \mathrm{Ma}$ (Fig. 9c).

\section{Discussion.}

6.1. Volume, location, timing and compositional variations of volcanism during the Late Jurassic

A significant feature of the Jurassic Andean system is the marked difference between the volume of the frontal arc volcanism and its proportion of differentiated material in comparison to the volcanic units of the back-arc domain. The thickness of Jurassic arc volcanic deposits in the Coastal Cordillera of northern Chile can reach about 7,000 m (Buchelt and Tellez, 1988; Muñoz et al., 1988), and they are composed of more than $80 \%$ of intermediate lava flows, with a minor amount of acid rocks. On the other hand, in the Precordillera and main Cordillera between 26 and $31^{\circ} \mathrm{S}$ the maximum thickness of Upper Jurassic volcanic rocks usually does not exceed $500 \mathrm{~m}$ (PF and AF, Jensen, 1976; Labbé et al., 2012; Rossel, 2011) and decrease even further to the east, no exceeding $200 \mathrm{~m}$ (LF and QVB, Cornejo et al., 1998; Iriarte et al., 1999; Tomlinson et al., 1999). The volume of differentiated volcanic material is significant in the PF and AF, but it is virtually absent in the easternmost units. It seems plausible to explain the observed differences between the volcanic units as a reflection of its location with respect to the margin (Grove et al., 2009).

As the volume of melt produced in the back-arc area is limited due to less availability of fluids, the content of incompatible elements in rocks from the retro-arc region increases (Stern et al., 2006; Tatsumi and Eggins, 1995). The latter is generally consistent with that observed in the back-arc rocks of northern Chile, where the PF, AF and LF lavas are more enriched in incompatible elements than the Jurassic arc rocks. The existence of rocks without $\mathrm{Nb}$-Ta anomalies among the LF volcanics suggests that the generation of magmas by hydration of the asthenospheric wedge is not the sole process involved in the back-arc magma genesis in northern Chile during the Late Jurassic and probably an enriched source, as prevalent or undepleted astenosphere, is involved too (Fig. 10a).

Based on their stratigraphic relationships, the QVB, located at the northern edge of the studied area (Fig. 1), are contemporary to the other units, but the volcanism here took place in a marine environment (Cornejo et al., 1998; Tomlinson et al., 1999), suggesting 
the absence of an emersion processes in that specific location. In addition, the chemistry differs from that of the other units and shows a tholeiite-like differentiation trend represented by $\mathrm{FeO}_{\mathrm{t}}$ enrichment and flat patterns for trace and $\mathrm{RE}$ elements (Figs. 3, 5 and $10 \mathrm{~b}, \mathrm{c})$ similar to those of the magmatic arc rocks in the Coastal Cordillera (Kramer et al., 2005; Oliveros el at., 2007), or back-arc tholeiites. Another distinguishing characteristic of the lavas of this unit is the high content of $\mathrm{V}$ relative to the other back-arc units. Given that $\mathrm{V}$ is preferably partitioned to titanomagnetite, its high concentration in the QVB suggests absence of this mineral phase in early stages of crystallization (tholeiitic trend) in comparison with the other units.

The features described above have been widely observed in modern arcs; where the volume of lava emitted in the retro-arc chains usually is less than $25 \%$ of the volume of igneous material observed in the contemporaneous volcanic front (Kimura and Yoshida, 2006; Stern et al., 2006; Taylor and Martinez, 2003). Although in southern Peru and northern Chile $\left(17^{\circ}-24^{\circ} \mathrm{S}\right)$ there are Middle and Upper Jurassic volcanic rocks in the Coastal Cordillera (Boekhout et al., 2012; Oliveros et al., 2006), between 26 and $31^{\circ} \mathrm{S}$ the outcrops of volcanic rocks of Late Jurassic age are scarce, suggesting a hiatus of the volcanic activity between $167.1 \pm 1.8 \mathrm{Ma}$ (age of the La Negra Formation) and $143.3 \pm 1.1$ (age of the ASVC, Emparan in press). This hiatus is significant because it is the same time span obtained for the volcanic rocks of the Precordillera and main Cordillera (163.2 \pm 1.4 $\mathrm{Ma}$ and $148.9 \pm 2.1 \mathrm{Ma}$ ), with the climax of back- arc magmatism at ca. 150 Ma standing largely during this period of apparent absence of volcanism in the Coastal Cordillera. Migration of the arc front during the late Jurassic, due to changes in slab configuration, could explain the diachronic volcanism in northern Chile. However, there are no significant unconformities within the Jurassic to Lower Cretaceous stratigraphic record that could support the deformation of the uppermost crust expected to occur under flat-slab conditions, and on the other hand, the existence of numerous Upper Jurassic intrusive bodies in the Coastal Cordillera indicates that arc activity was not interrupted, or in a seaward position during this period, and that contemporaneous magmatism was taking place further to the east, in the back-arc region.

\subsection{Constrains on magma sources.}

Based on the geochemical characteristics of the studied lavas, we can set some parameters regarding the source and the conditions of the back-arc volcanism during the Late Jurassic. High $\mathrm{Mg} \#, \mathrm{MgO}$ and low $\mathrm{SiO}_{2}$ contents in some samples of the PF and LF are indicative of parental magmas. The parallel REE patterns in samples of each formation suggest that the less primitive lavas were originated by fractional crystallization of the more primitive ones. The high content of $\mathrm{Al}_{2} \mathrm{O}_{3}$ in a group of lavas of $\mathrm{LF}$ and $\mathrm{PF}$ could be indicative of melting of subducted sediments in the back-arc area but this is not clearly evidenced by the isotopic signal. The HREE patterns in these rocks is consistent with the presence of small amounts of residual garnet in the source, and thus restricts the depth of 
magma generation to at least $50 \mathrm{~km}$, probably in the transition between the stability field of spinel and garnet lherzolites. Sample PR-10-73 of the LF has the lowest Yb content (about 4 times the chondrite), therefore the parental magma of this rock was originated at even greater depths. With regard to the $\mathrm{Eu}$, the analyzed rocks have either inexistent or very slight negative anomalies, indicating that plagioclases were not significantly fractionated during crystallization from the parental magmas.

The spider diagrams of the back-arc lavas show patterns typical of subductionrelated magmatism with high LILE contents respect to HFSE, positive $\mathrm{Pb}$ anomalies, $\mathrm{Ti}$ depletion and $\mathrm{Nb}$-Ta troughs, suggesting the direct involvement of fluids released from the slab in the generation of magmas (Pearce, 1982). The sole exception is a subset of rocks of the LF, without $\mathrm{Nb}$-Ta anomaly (Fig. 4d and 10), that could have a different mantle source (see below). While most of the studied samples exhibit negative $\mathrm{Nb}$-Ta anomalies, they are not as marked as those observed in arc rocks, and become increasingly less evident in the eastern units, as expressed by variations in $\mathrm{La} / \mathrm{Nb}$ ratios (Fig. 11). This suggests the existence of an increasingly enriched mantle to the east since, as proposed by the back-arc evolution model of Taylor and Martinez (2003), the mantle directly under the main arc is more depleted due to a higher volume of magma generated from it, while to the back-arc the mantle is more enriched. However, some QVB rocks do not fit this model, because they exhibit some of the most pronounced $\mathrm{Nb}$-Ta anomalies but are in a position similar to that of LF, implying that the generation of these lavas is related to a different process, that likely involves decompression of a highly depleted mantle assisted by subduction derived fluids.

The isotopic signature of the back-arc lavas shows a trend slightly more radiogenic than the arc rocks, but still consistent with mantle derived melts $\left(\varepsilon \mathrm{Nd}_{\mathrm{i}}>0\right)$, except for the most differentiated samples of LF which have negative $\varepsilon \mathrm{Nd}_{i}$ values (Fig. 6). This behavior could be related to a small contribution of the basement, mainly composed by PermoTriassic and Paleozoic granitic intrusives (Cornejo et al., 1998; Iriarte et al., 1999; Nasi et al., 1986; Tomlinson et al., 1999). An upper crustal contribution to back-arc magmatism makes sense when taking into account that the rocks with the highest $\varepsilon \mathrm{Nd}$ values are those of the QVB. These rocks are also characterized by flatter multi-element patterns, tholeiitic affinities and being the only ones erupted in a submarine environment, suggesting that they could have been formed in the basin with the highest amount of subsidence, over the thinnest crust of the back-arc region. $\mathrm{Pb}$ isotopes are more sensitive to the contribution of an enriched source given the low amount of radiogenic $\mathrm{Pb}$ in the mantle. The isotopic composition of the back-arc lavas suggests the involvement of a more radiogenic component in the genesis of those magmas. Particularly, Pb signal of LF lavas seems to be extremely enriched, even more than the mean Paleozoic crust, discarding these as the only source of enrichment in the back-arc, and suggesting the participation of a HIMU source at least in the generation of the LF lavas. 
In order to approach the likely source of the Late Jurassic arc and back-arc lavas, Equilibrated Melting, Assimilation and Fractional Crystallization (AFC) and mixing modeling, using IgPet 2010, was performed to the most primitive arc and back-arc samples (Fig. 12). The results show that it is possible to achieve the compositional features of the Jurassic arc rocks by melting of depleted mantle, assimilation of low amounts of middle or lower continental Crust ( $\mathrm{R}$ factor under 0.3 ) and 40 to $60 \%$ fractionation of the primitive melt. These processes explain the low $\mathrm{Ni}, \mathrm{Cr}$ and \#Mg in the arc lavas. On the other hand, the results plotted in the $\mathrm{TiO}_{2}$ vs $\mathrm{Nb} / \mathrm{Yb}$ diagram (Fig. 12a), suggest late crystallization of magnetite for the arc lavas and particularly for the QVB rocks, which is consistent with their tholeiitic affinity. In order to achieve the composition of the PF, AF and some of the LF rocks, low melting degrees of a mixture of primitive and depleted mantle is needed, and the presence of low amounts of garnet in the source.

The bimodal distribution of samples with OIB-like signature in LF seem to follow a vertical array in the diagrams (segmented line in Fig. 12b), which is consistent with a source rich in garnet, such as garnet lherzolites, that is typical of deep mantle sources. The observed variations in $\mathrm{Nb} / \mathrm{Yb}$ ratios might be the result of different melting degrees.

Once the degrees of melting and other parameters for the preliminary source of the sub-arc mantle have been set, the Arc Basalt Simulator 2 (ABS2) of Kimura et al., (2009) is used for further modeling of two arc samples (K-16, Kramer et al., 2005 and VO3, Oliveros et al., 2007). The results indicate that the arc magma source could be Primitive Mantle with 1 to $2 \%$ of previous extraction that is melted in the presence of $2.5 \%$ of $\mathrm{H}_{2} \mathrm{O}$ generated mainly by sediment dehydration in the slab. A good fit is achieved for the immobile elements, whereas the mismatch with the more mobile elements could be due to late alterations processes. The ABS2 modeling results for the back-arc basalt of the PF indicate a Primitive Mantle with $0.3 \%$ of previous extraction as the likely source, melted in the presence of up to $1.2 \%$ of $\mathrm{H}_{2} \mathrm{O}$, generated by sediment and altered oceanic crust dehydration. A good fit is achieved for both immobile and mobile elements but not for the isotopic ratios.

The obtained results indicate that the mantle source for the rocks of the PF is probably the same of the arc rocks, but with lesser extents of previous extraction. This is consistent with the more alkaline character of the back-arc volcanics, generated from minor amounts of melting of the source, their higher concentrations of $\mathrm{Nb}$ and $\mathrm{Ta}$, and with the likely deeper source of the magmas as suggested by their HREE contents. The QVB lavas were originated under similar conditions to those of the arc, from a depleted mantle source but at lower depths, as suggested by its more tholeiitic character, which would explain the high content of $\mathrm{V}$ (late fractionation of titanomagnetite) and flatter patterns of incompatible elements. 
The high $\mathrm{Nb}$ contents of the second group of LF lavas (without $\mathrm{Nb}-\mathrm{Ta}$ anomalies), the shape of the spider diagrams and their isotopic signature suggest that the parental magmas of these rocks are derived from a different mantle source. The occurrence of OIBlike volcanic rocks has been reported in several island arcs and some continental arcs; they are characterized by higher $\mathrm{Nb}$ contents $(>20 \mathrm{ppm})$ than typical calcalkaline rocks $(\approx 5$ ppm) and thus named High $\mathrm{Nb}$ basalts (HNB) or Nb enriched basalts (NEB). The question of how magmas with an intraplate signature are generated within a subduction zone has been addressed by many authors. Two-stage melting of an OIB sub-arc mantle under different oxidizing conditions was invoked to explain the coexistence of calcalkaline basalts and NEB in the Turrialba volcano in Costa Rica. Saturation in rutile or another Ti$\mathrm{Nb}$-Ta phase due to high $\mathrm{fO}_{2}$ would be responsible for the HFSE depletion of the calcalkaline suite since the magma source was the same for both groups of volcanic rocks, as inferred from trace elements and isotopic composition (Reagan and Gill, 1989).

Although this model could explain the coexistence of the LF lavas with and without Nb-Ta anomaly, the trace elements and isotopic signature of these Andean rocks points out to different magma sources. Another possibility to generate high $\mathrm{Nb}$ magmas in a subduction zone would be through melting of a young hot slab $(<25 \mathrm{Ma})$. HNB have been related to adakitic magmas in arcs such as Kamchatka (Kapezhinskas et al., 1996), Panamá and Costa Rica (Defant et al., 1992), Cascadias (Defant and Drummond, 1993) and Baja California (Aguillón-Robles et al., 2001). Slab-derived melts can crystallize as adakites when they do not interact with the sub-arc mantle wedge, but if they metasomatize the peridotitic mantle and this is later melted the likely product would be the NEB (Kapezhinskas et al., 1996). This process could also explain the genesis of the LF lavas, however neither the back-arc units nor the arc rocks have adakitic signatures, such as high $\mathrm{Sr} / \mathrm{Y}$, and it is unlikely that the slab was young enough to melt because by the late Jurassic subduction had been active for at least 50 Myr. Finally, a third scenario that does not require contemporary slab melting or the same source for alkaline and calcalkaline magmas is the occurrence of enriched zones, such as prevalent or OIB-type mantle or metasomatized mantle (linked to prior slab melting/dehydration processes) within the asthenospheric wedge (Macpherson et al. 2010; Petrone et al., 2003; Petrone y Ferrari, 2008). Based on the geochemistry of lavas from the Sulu arc Macpherson et al. (2010) proposed the presence of an OIB-like component in the convective upper mantle; magmatism resulted from upwelling of such OIB-like domains into lithospheric thin spots that were produced during prior subduction. Decompression melting of such undepleted domains and the lithosphere due to extensional tectonic regime in the Andean back-arc is a plausible hypothesis to explain the elemental and isotopic signature of the alkaline lavas of the LF and its coexistence with the subduction signature volcanic rocks. 
The first stage of Andean evolution (Jurassic to Early Cretaceous) is thought to have developed mainly under extensional regime (Grocott and Taylor, 2002, Parada et al., 1999; Mpodozis and Ramos, 1988; Scheuber and González, 1999). However, as described in section 6.1, tectonic condition during this period in the Andean margin would not have been as homogeneous as previously documented since there are changes in the location and timing of magmatism. Such changes are not restricted only to the studied area, for instance, Boekhout et al., (2012) have documented the existence of an important gap in the plutonism of the Southern Peruvian Batholiths between 152 and $110 \mathrm{My}$, following a period of slab roll-back that caused rapid extension and lithospheric thinning in the margin. In central Chile $\left(33^{\circ}-35^{\circ} \mathrm{S}\right)$ there is no clear evidence of deposition of volcanic rocks during the late Jurassic in the arc region (present-day Coastal Cordillera), but the effusion of a significant volume of lavas took place further east, represented by thick volcanic successions in the Río Damas Formation in the Principal Cordillera (Klohn, 1960).

Perhaps one of the most important changes in the configuration of the Andean margin paleogeography is the marine regression that took place in the back-arc basins of northern and central Chile during Upper Jurassic (Ardill et al., 1998; Mescua et al., 2011; Vicente et al., 2006). The period in which the sea retreated, leaving the southern part of the Tarapacá basin and the entire Neuquén basin exposed to continental sedimentation, broadly coincides with the developing of back-arc volcanism and the regression has been associated with the beginning of generation of oceanic floor between eastern and western gondwana (Ardill. et al., 1998). It is possible that this major geological event could have triggered changes in the configuration of the volcanic system developed in northern Chile between $26^{\circ}$ and $31^{\circ} \mathrm{S}$.

Particularly, in the studied area the geochemical features of the Upper Jurassic units show a variation in the composition of the volcanism, with effusion of rocks that grade from calc-alkaline to transitional between calc-alkaline and alkaline or even exclusively alkaline or tholeiitic in the easternmost units. The variation from calcalkaline to transitional/alkaline, and more enriched, compositions observed between the arc and the westernmost back-arc units probably reflect the K-h dependence (increase of alkalinity with increasing distance between the emission center and the Wadatti-Beniof zone) of the magmas and less availability of water in the back-arc area, combined with the presence of a less depleted mantle source to the east and minor involvement of the Paleozoic basement, as suggested by the isotope compositions and the results of the melting models.

The compositional features of the easternmost units in the back-arc region seem to reflect a process for magma generation different from the arc. The LF lavas without $\mathrm{Nb}-\mathrm{Ta}$ anomaly exhibit higher incompatible elements content and alkalinity that is not necessarily related to a progressive enrichment of the mantle to the east or K-h dependence, but rather to the influence of a completely different source, probably from a enriched mantle domain as suggested by the OIB-like pattern and $\mathrm{Pb}$ isotopes. The emplacement of these lavas is 
spatially linked to an important Triassic depocenter (Iriarte et al., 1999). It is possible that the ascent of magmas with intraplate signature could have been facilitated by the reactivation of faults associated to the Triassic basins. On the other hand, the QVB lavas seem to be derived from a more depleted and shallower mantle source, as suggested by their $\mathrm{Nd}$ isotope compositions and tholeitic affinities. A progressive thinning of the continental crust, evidenced by the presence of important Jurassic depocenters in the emplacement area of the QVB lavas (Cornejo et al., 1998; Tomlinson et al., 1999), could have triggered the decompression melting of the upper mantle, assisted by the presence of fluids derived from the slab (Fig. 13).

In spite of being a continental arc, the configuration of the Andean margin during late Jurassic has some features of the extensional modern island arcs of western Pacific region: (i) a clear development of a secondary retro-arc represented by the PF and AF, (ii) an extensional volcanism more to the east in the back-arc, in a continental environment (LF) or, locally, under submarine conditions (QVB) (Fig. 13). On the other hand, the geochemistry of the volcanic rocks seems to be controlled by the K-h factor in addition to heterogeneous magma sources and probably complex mantle dynamics. Whatever the origin of the observed differences, this particular configuration is not an isolated event in the geological history of Gondwana margin. Recently, Alasino et al. (2012), have shown that similar transitional features are observed in the geochemistry of plutonic rocks of the Early Carboniferous Western and Eastern Sierras Pampeanas, effused in a continental extensional configuration, which seems to suggest the existence of a cyclical evolution in this long-lived subduction margin at this latitudes.

\section{Conclusions}

The Upper Jurassic volcanic rocks located in the Precordillera and main Cordillera of northern Chile $\left(26^{\circ}-31^{\circ}\right)$ belong to volcano-sedimentary units that were deposited in a back-arc basin during a period of sea retreat and continental sedimentation along the Andean margin. They crop out as two belts aligned parallel and east to the Jurassic - Early Cretaceous arc. Elemental and isotopic geochemical data of these rocks indicate that they are subduction-related but have systematical differences from frontal arc magmatism.

Rocks belonging to the western belt (closer to the arc front) have steeper multielement patterns, higher concentrations of incompatible elements and lower concentrations of HREE relative to arc magmatism. This suggests the involvement of deep mantelic sources for the back-arc volcanism, which is consistent with its position farther from the trench. The eastern belt is composed by rocks that are compositionally more hetereogeneous: one group has similar characteristic as the western belt (AF and PF), another has flat multielements patterns and tholeiitic affinities (QVB) suggesting a shallow 
mantle as the magmatic source; and a third group with alkaline affinities and lacking of $\mathrm{Nb}$ $\mathrm{Ta}$ anomalies. The generation of this group requires the involvement of an OIB-type mantle as the magma source.

$\mathrm{Nd}-\mathrm{Sr}$ and $\mathrm{Pb}$ composition for the majority of back-arc volcanics can be reproduced by a mixture of depleted mantle with variable but small amounts of a more radiogenic source probably represented by the continental crust. The group of rocks lacking of $\mathrm{Nb}-\mathrm{Ta}$ anomaly (LF) have very high radiogenic $\mathrm{Pb}$ composition, and require the involvement of a third end member represented by an OIB-type mantle.

$\mathrm{Ar}-\mathrm{Ar}$ and $\mathrm{U}-\mathrm{Pb}$ geochronology of igneous minerals indicate that back-arc volcanism took place from $163.9 \pm 1.4$ to $148.9 \pm 2.1 \mathrm{Ma}$, whereas one age from the upper part of the La Negra formation (arc volcanism) yield an U-Pb age of $167.1 \pm 1.8 \mathrm{Ma}$. Although there is no geochronological evidence of coeval volcanism in the arc and backarc domains at these latitudes, numerous plutonic bodies of upper Jurassic age crop out in the Coastal Cordillera (arc domain) suggesting that magmatism did not shift its position at that time.

In spite the fact that the Jurassic Andean arc was built over a continental plate, the architecture of the volcanic chains and geochemical variations observed among the arc and back-arc rocks in northern Chile resemble those in modern island arcs, and thus support the hypothesis that early Andean subduction developed under extensional tectonic conditions. 


\section{References}

Aguillón-Robles, A., Calmus, T., Benoit, M., Bellon, M.H., Maury, R.C., Cotten, J., Bourgois, J., Michaud, F. 2001. Late Miocene adakites and Nb-enriched basalts from Vizcaino Peninsula, Mexico: indicators of East Pacific Rise subduction below southern California? Geology 19, 531-534.

Alasino, P.H., Dahlquist, J.A., Pankhurst, R.J., Galindo, C., Casquet, C., Rapela, C.W., Larrovere, M.A., Fanning, C.M. 2012. Early Carboniferous sub- to mid-alkaline magmatism in the Eastern Sierras Pampeanas, NW Argentina: A record of crustal growth by the incorporation of mantle-derived material in an extensional setting. Gondwana Research 22, 992-1008.

Amilibia, A., Sàbat, F., McClay, K.R., Muñoz, J.A., Roca, E., Chong, G. 2008. The role of inherited tectonosedimentary architecture in the development of the central Andean mountain belt: Insights from the Cordillera de Domeyko. Journal of Structural Geology 30 (12), 1520-1539.

Ardill, J., Flint, S., Chong, G., Wilke, H. 1998. Sequence stratigraphy of the Mesozoic Domeyco Basin, Northern Chile. Journal of the Geological Society of London 155, 71-88.

Arévalo, C. and Walkner, D. 2008. Geología del Área Carrizal bajo-Chacritas, Región de Atacama. Servicio Nacional de Geología y Minería. Mapas Geológicos 111. Escala 1:100.000. Santiago.

Boekhout, F., Spikings, R., Sempere, T., Chiaradia, M., Ulianov, A., Schaltegger, U. 2012. Mesozoic arc magmatism along the southern Peruvian margin during Gondwana breakup and dispersal. Lithos 146-147, 48-64.

Buchelt, M., Téllez, C. 1988. The Jurassic La Negra Formation in the area of Antofagasta, northern Chile (lithology, petrography, geochemistry). In: Bahlburg, H., Breitkreuz, C., Giese, P. (Eds.), The Southern Central Andes. Lecture Notes in Earth Sciences 17, 171-182.

Cabanis, B., Lecolle, M. 1989. Le diagramme La/10-Y/15-Nb/8: un outil pour la discrimination des séries volcaniques at la mise en évidence des processus de mélange et/ou de contamination crustales. Comptes Rendus de l'Academie de Sciences de Paris série II 309, 2023-2029.

Charrier, R., 1979. El Triásico en Chile y regiones adyacentes de Argentina: Una reconstrucción paleogeográfica y paleoclimática. Comunicaciones 26, 1-37.

Charrier, R., Pinto, L., Rodriguez, M. P. 2007. Tectonoestratigraphic evolution of the Andean Orogen in Chile. In: Moreno, T., Gibbons, W (Eds.), The Geology of Chile. The Geological Society, London, p. 21144.

Cornejo, P., Mpodozis, C., Ramirez, C.F., Tomlinson, A. J. 1993. Estudio Geológico de la Región de Potrerillos y El Salvador $\left(26^{\circ}-27^{\circ}\right.$ Lat. S). Servicio Nacional de Geología y Minería. Informe Registrado IR-93-01. 258 p. 12 mapas. Escala 1:50.000. Santiago.

Cornejo, P., Mpodozis, C., Tomilson, A.J. 1998. Hoja Salar de Maricunga, Región de Atacama. Servicio Nacional de Geología y Minería Mapas Geológicos 7: 1 mapa. Escala 1:100.000. Santiago.

Creixell, C., Parada, M.A., Morata, D., Roperch, P., Arriagada, C. 2009. The genetic link between mafic dike swarms and plutonic reservoirs in the Mesozoic of central Chile ( $\left.30^{\circ}-33^{\circ} 45^{\prime} \mathrm{S}\right)$ : insights from AMS and geochemistry. International Journal of Earth Sciences 98, 177-201.

Defant, M.J., Jackson, T.E., Drummond, M.S., de Boer, J.Z., Bellon, H., Feigenson, M.D., Maury, R.C., Stewart, R.H. 1992 The geochemistry of young volcanism throughout western Panama and southern Costa Rica, an overview. Journal of the Geological Society of London 149, 569-579.

Defant, M.J., Drummond, M.S. 1993. Mount St. Helens: potential example of the partial melting of the subducted lithosphere in a volcanic arc. Geology 21, 547-550.

DePaolo D.J. 1981. Trace element and isotopic effects of combined wallrock assimilation and fractional crystallization. Earth and Planetary Science Letters 53, 189-202.

Drew S., Ducea M., Schoenbohm L. 2009. Mafic volcanism on the Puna Plateau, NW Argentina: Implications for lithospheric composition and evolution with an emphasis on lithospheric foundering. Lithosphere 1, 305-318

Ducea, M.N., and Saleeby, J.B. 1998. The age and origin of a thick mafic ultramafic root from beneath the Sierra Nevada batholiths. Contributions to Mineralogy and Petrology 133, 169-185. 
Emparan, C. in press. Geologia area Ovalle-Peña Blanca, Region de Coquimbo. Servicio Nacional de Geología y Minería, Serie Geologia Basica xx escala 1:100,000.

Emparan, C., Pineda, G., 2000. Área La Serena-La Higuera, Región de Coquimbo. Servicio Nacional de Geología y Minería, Mapas Geológicos 18. Escala 1:100,000. Santiago.

Faure, G. 1986. Principles of Isotope Geochemistry. NewYork: JohnWiley, 464 p.

Faure, G. and Mensing, T. M., 2005. Isotopes: Principles and Applications. NewYork: JohnWiley, 928 p.

Galer, S.J.G., Abouchami, W., 2004. Mass bias correction laws suitable for MC-ICP-MS measurement. Geochimica et Cosmochimica Acta 68, A542-A542.

Gehrels, G. E., Valencia, V. A., Ruiz, J. 2008. Enhanced precision, accuracy, efficiency, and spatial resolution of $\mathrm{U} / \mathrm{Pb}$ ages by laser ablationmulticollector inductively coupled plasma mass spectrometry, Geochemistry Geophysics Geosystems, 9, Q03017, doi:10.1029/2007GC001805.

Grocott, J. and Taylor, G.K. 2002. Magmatic arc fault systems, deformation partitioning and emplacement of granitic complexes in the Coastal Cordillera, north Chilean Andes ( $25^{\circ} 30^{\prime} \mathrm{S}$ to $\left.27^{\circ} 00^{\prime} \mathrm{S}\right)$. Journal of the Geological Society, 159 (4), 425-442.

Grove, T. L., C. B. Till, E. Lev, N. Chatterjee, and E. Medard 2009, Kinematic variables and water transport control the formation and location of arc volcanoes. Nature, 459, 694-697

Hallam, A., Biro-Bagoczky, L., Pérez, E., 1986. Facies analysis of the Lo Valdes Formation of the High Cordillera of central Chile, and the paleogeographic evolution of the Andean basin. Geological Magazine 123 (4), 425-435.

Hallam, A. 1991. Relative importance of regional tectonics and eustasy for the Mesozoic of the Andes. In: Macdonald, D.I.M. (Ed.), Sedimentation, Tectonics and Eustasy: Sea-level Changes at Active Margins, vol. 12. Special publication of the International Association of Sedimentologists, pp. 189-200.

Harrington, H. 1961. Geology of parts of Antofagasta and Atacama provinces of northern Chile. American Association of Petroleum Geologists, Bulletin 45 (2), 169-197.

Hart, S. R. 1984. A large-scale isotope anomaly in the Southern Hemisphere mantle. Nature 309, 753-757.

Howell, J.A., Schwarz, E., Spalletti, L.A., Veiga, G.D., 2005. The Neuquén Basin, Argentina: An Overview. In: Veiga, G. D., Spalletti, L. A., Howell, J. A. and Schwarz, E. (eds.), The Neuquén Basin: a case study in sequence stratigraphy and basin dynamics. Geological Society of London, Special Publications, pp. 1-14.

Irirate, S., Mpodozis, C., Gardeweg, M. 1995. Mapa geológico de la Hoja Laguna del Negro Francisco. Servicio Nacional de Geología y Minería. Documento de Trabajo 9. Escala 1:100,000.

Iriarte, S., Arévalo, C., Mpodozis, C. 1999. Mapa Geológico de la Hoja La Guardia, Región de Atacama. Servicio Nacional de Geología y Minería. Mapa Geológico 13. Escala 1:100,000. Santiago.

Jenks, W. 1948. Geología de la hoja de Arequipa, Escala 1:200.000. Boletín del Instituto Geológico del Perú, 9, $104 \mathrm{p}$.

Jensen, O. 1976. Geología de las Nacientes del río Copiapó, entre los $27^{\circ} 53^{\prime}$ y $28^{\circ} 20^{\prime}$ de latitud Sur, provincia de Atacama, Chile. Memoria de Título. Departamento de Geología, Universidad de Chile.

Kepezhinskas, P., Defant, M.J., Drummond, M.S. 1996. Progressive enrichement of island arc mantle by melt-periodotite interaction inferred from Kamchatcka xenoliths. Geochimica et Cosmochimica Acta 60, $1217-1229$.

Kimura, J. and Yoshida, T. 2006. Contributions of slab fluid, mantle wedge and crust to the origin of Quaternary lavas in the NE Japan Arc. Journal of Petrology 47 (11), 2185-2232.

Kimura, J-I., Hacker, B., van Keken, P., Kawabata, H., Yoshida, T., Stern, R. 2009. Arc Basalt Simulator version 2, a simulation for slab dehydration and fluid-fluxed mantle melting for arc basalts: Modeling scheme and application. Geochemistry, Geophysics, Geosystems, 10 (9), 1525-2027.

Klohn, C. 1960. Geología de la Cordillera de los Andes de Chile Central, Provincias de Santiago, O'Higgins, Colchagua y Curicó. Investigaciones Geológicas (Chile), Boletín n 8, 95 p. Santiago.

Kramer, W., Siebel, W., Romer, R., Haase, G., Zimmer, M., Ehrlichmann, R. 2004. Geochemical and isotopic characteristics and evolution of the Jurassic volcanic arc between Arica $\left(18^{\circ} 30^{\prime} \mathrm{S}\right)$ and Tocopilla $\left(22^{\circ} \mathrm{S}\right)$, North Chilean Coastal Cordillera. Chemie der Erde, 65, 47-78. 
Labbé, M., Salazar, E., Rossel, P., Merino, R., Oliveros, V. 2012. Variaciones laterales en la arquitectura estratigráfica del Jurásico superior en el valle del Tránsito: Evidencias del desarrollo de un rift continental. In: Congreso Geológico Chileno, No. 13, Antofagasta.

LeMaitre, R.W. 1989. A classification of igneus rocks and glossary of therms. Blackwell Scientific Publication: 193 p. London.

Lucassen, F., Franz, G., 1994. Arc related Jurassic igneus and meta-igneus rocks in the Coastal Cordillera of northern Chile/ Region Antofagasta. Lithos 32, 273-298.

Lucassen, F., Escayola, M., Romer, R.L., Viramonte, J. Koch, K., Franz, G. 2002. Isotopic composition of Late Mesozoic basic and ultrabasic rocks from the Andes (23-32 $\mathrm{S})$ : implications for the Andean mantle. Contributions to Mineralogy and Petrology 143, 336-349.

Lucassen, F., Kramer, W., Bartsch, V., Wilke, H. G., Franz, G., Romer, R. L., Dulski, P. 2006. Nd, Pb and Sr isotope composition of juvenile magmatism in the Mesozoic large magmatic province of northern Chile $\left(18^{\circ}-27^{\circ} \mathrm{S}\right)$ : indications for a uniform subarc mantle. Contributions to Mineralogy and Petrology 152, 571589.

Ludwig, K. R. 2003, User's manual for isoplot 3.00: A geochronological toolkit for Microsoft Excel, Berkeley Geochronological Center Special Publication 4, 71 pp., Berkeley, California.

MacPherson, C.G., Chiang, K.K., Hall, R., Nowell, G.M., Castillo, P.R., Thirlwall, M.F. 2010. PlioPleistocene intra-plate magmatism from the southern Sulu Arc, Semporna peninsula, Sabah, Borneo: implications for high-Nb basalt in subduction zones. Journal of Volcanology and Geothermal Research 190, 25-38

Martin, M.W., Clavero, J.R., Mpodozis, C.M. 1995. Estudio geológico regional de la franja del Indio, Cordillera de Coquimbo: Informe registrado II-95-6, Servicio Nacional de Geología y Minería, Chile y Compañía Minera San José, 232 p. 4 Mapas escala 1:50.000 Santiago, Chile.

Martinez, F., Arriagada, C., Mpodozis, C., Peña, M. 2012. The Lautaro Basin: A record of inversion tectonics in northern Chile. Andean Geology 39 (2), 258-278.

Marschik, R., Fontboté, L. 2001. The Punta del Cobre Formation, Punta del Cobre-Candelaria area, northern Chile. Journal of South American Earth Sciences 14, 401-433.

McDonough, W.F. and Sun, S.S. 1995. The composition of the Earth. Chemical Geology 120, 223-253.

MacLean, W.H. and Barrett, T.J. 1993. Lithogeochemical methods using immobile elements. Journal of Exploration Geochemistry 48, 109-133.

Mescua, J.F. 2011. Evolución estructural de la cordillera principal entre Las Choicas y Santa Elena $\left(35^{\circ} \mathrm{S}\right)$, provincia de Mendoza, Argentina. (PhD Thesis). Universidad de Buenos Aires. 241p.

Moscoso, R., Mpodozis, C., Nasi, C., Ribba, L., Arévalo, C., in press. Geología de la Hoja El Tránsito, Región de Atacama. Servicio Nacional de Geología y Minería. Carta Geológica de Chile, Serie Preliminar, 1 mapa. Escala 1: 250.000. Santiago.

Mpodozis, C., Cornejo, P., 1986. Hoja Pisco Elqui. Servicio Nacional de Geología y Minería, Carta Geológica de Chile. Escala 1: 250,000. Santiago.

Mpodozis, C., Ramos, V., 1989. The Andes of Chile and Argentina. In: Ericksen, G. E., Cañas, M. T., Reinemund, J. A. Geology of the Andes and its relation to hydrocarbon and energy resources. Circum Pacific Council for Energy and Hydrotermal Resources, Huston, Earth Science Series 11, 59-90.

Mpodozis, C., Ramos, V., 2008. Tectónica Jurásica en Argentina y Chile: Extensión, subducción oblicua, rifting, deriva y colisiones? Revista de la Asociación Geológica Argentina, 63 (4), 481-497.

Muñoz, N., Venegas, R., Téllez, C. 1988. La Formación La Negra: Nuevos antecedentes estratigráficos en la Cordillera de la Costa de Antofagasta. In Congreso Geológico Chileno, No. 5, Actas 1, A283 - A311.

Nasi, C., Moscoso, R., Maksaev, V. 1986. Hoja Guanta, Regiones de Atacama y Coquimbo. Servicio Nacional de Geología y Minería. Carta Geológica de Chile 67, 141 p. Santiago.

Oliveros, V., Féraud, G., Aguirre, L., Fornari, M., Morata, D. 2006. The Early Andean Magmatic Province (EAMP): 40Ar/39Ar dating on Mesozoic volcanic and plutonic rocks from the Coastal Cordillera, Northern Chile. Journal of Volcanology and Geothermal Research 157, 311-330. 
Oliveros, V., Morata, D., Aguirre, L., Féraud, G., Fornari, M. 2007. Jurasic to Early Cretaceus subductionrelated magmatism in the Coastal Cordillera of northern Chile ( $\left.18^{\circ} 30^{\prime}-24^{\circ} \mathrm{S}\right)$ : geochemistry and petrogenesis. Revista Geológica de Chile 34, 209-232.

Oliveros, V., Labbé, M., Rossel, P., Charrier, R., Encinas, A. 2012. Late Jurassic paleogeographic evolution of the Andean back-arc basin: new constrains from the Lagunillas Formation, northern Chile (27 $30^{\prime}$ $28^{\circ} 30^{\prime}$ 'S). Journal of Southamerican Earth Sciences 35, 25-40.

Otamendi, J.E., Ducea, M.N., Tibaldi, A.M., Bergantz, G., de la Rosa, J.D., Vujovich, G.I. 2009. Generation of tonalitic and dioritic magmas by coupled partial melting of gabbroic and metasedimentary migmatites in the deep crust of the Famatinian arc Argentina. Journal of Petrolgy 50, 841-873.

Palacios, C. 1978. The Jurassic paleovolcanism in northern Chile. (PhD Thesis). Tübingen University: 99 p.

Pearce, J.A. 1982. Trace elements characteristics of lavas from destructive plate boundaries. In: Thorpe R.S. (Ed). Andesites. Jhon Wiley and Sons, 525-548. London.

Pearce, J.A. 1983. Role of the sub-continental lithosphere in magma genesis at active continental margins. In: Hawkesworth, C.J., Norry, M.J. (Eds.), Continental basalts and mantle xenoliths. Shiva, Nentwich, p. 230249.

Petrone, C.M. Francalanci, L. Carlson, R.W. Ferrari, L. Conticelli, S. 2003. Unusual coexistence of subduction-related and intraplatetype magmatism: $\mathrm{Sr}, \mathrm{Nd}$ and $\mathrm{Pb}$ isotope and trace elements data from the magmatism of the San Pedro-Ceboruco graben (Nayarit, Mexico). Chemical Geology 193, 1-24.

Petrone, C., Ferrari, L. 2008. Quaternary adakite-Nb-enriched basalt association in the wastern TransMexican Volcanic Belt: is there any slab melt evidence? Contributions to Mineral Petrology 156, 73-86.

Pichowiak, S. 1994. Early Jurassic to Early Cretaceous magmatism in the Coastal Cordillera and the Central Depression of North Chile. 203-217. In: Reutter, K-J., Scheuber, E., Wigger, P.J. (eds.), Tectonics of the Southern Central Andes. Structure and evolution of an continental margin. Springer Verlag. Stuttgart.

Ramos, V.; Alemán, A. 2000. Tectonic Evolution of the Andes. In: Cordani, U.G.; Milani, E.J.; Thomaz Filho, A.; Campos, D.A. (Eds.), Tectonic evolution of South America. International Geological Congress, No. 31, p. 635-685. Río de Janeiro.

Raegan, M., Gill, J. 1989. Coexisting calcalkaline and high-Niobium basalts from Turrialba Volcano, Costa Rica: Implications for residual titanates in arc magma source. Journal of Geophysical Research 94, 46194633.

Ribba, L. 1986. Geología del Cuadrángulo El Tránsito, Región de Atacama, Chile. Memoria de Título (Inédito), Universidad de Chile, Departamento de Geología: 214 p.

Rickwood, P.C. 1989. Boundary lines within petrologic diagrams which use oxides of mayor and minor elements. Lithos 22, 247-263.

Rivano, S., Sepúlveda, P. 1986. Hoja Illapel. Servicio Nacional de Geología y Minería. Carta Geológica de Chile No.69. Santiago.

Rogers, G., Hawkesworth, C.J., 1989. A geochemical traverse across the North Chilean Andes: evidence for crust generation from the mantle wedge. Earth and Planetary Science Letters. 91, 271-285.

Rossel, P. 2011. Caracterización petrográfica de las rocas volcánicas del Jurásico Superior-Cretácico Inferior, aflorantes en la Precordillera chilena entre los $26^{\circ}$ y $31^{\circ} \mathrm{S}$. Memoria para optar al título de Geólogo (Inédito), Universidad de Concepción, Departamento de Ciencias de la Tierra, 83 p.

Rudnick R. L. and Gao S. 2003. Composition of the continental crust, in: Rudnick, R. L. (Ed.). The Crust, vol. 3. Elsevier, pp. 1-64.

Scaillet, S. 2000. Numerical error analysis in Ar-40/Ar-39 dating. Chemical Geology 162 (3-4), 269-298.

Scaillet S., Rotolo S.G., La Felice S., Vita-Scaillet G. 2011. High-resolution ${ }^{40} \mathrm{Ar} /{ }^{39} \mathrm{Ar}$ chronostratigraphy of the post-caldera $(<20 \mathrm{ka})$ volcanic activity at Pantelleria, Sicily Strait. Earth and Planetary Science Letters 309, 280-290.

Scheuber, E. and González, G. 1999. Tectonics of the Jurasic-Early Crataceous magmatic arc of the north Chilean Coastal Cordillera $\left(22^{\circ}-26^{\circ} \mathrm{S}\right)$ : A story of crustal deformation along a convergent plate boundary. Tectonics 18, 895-910. 
SERNAGEOMIN, 2003. Mapa Geológico de Chile: versión digital, vol. 4. Servicio Nacional de Geología y Minería, Publicación Geológica Digital, Santiago.

Soffia, J.M. 1989. Estratigrafía y geología estructural del área del río Jorquera, Región de Copiapó. Memoria de Título. Universidad de Chile, Departamento de Geología, 159 p.

Stacey, J. S. and Kramers, J. D. 1975. Approximation of terrestrial lead isotope evolution by a two-stage model. Earth and Planetary Science Letters 26, 207-221.

Stern, R.J., Kohut, E.J., Bloomer, S.H., Leybourne,M., Fouch, M., Vervoot, J. 2006. Subduction factory processes beneath the Guguan cross-chain,Mariana Arc: no role for sediments, are serpentinites important? Contributions to Mineralogy and Petrology 151 (2), 202-221.

Sun, S.S. and McDonough, W.F. 1989. Chemical and isotopic systematics of oceanic basalts: implications for mantle composition and processes. Geological Society Special Publication 42, 313-345.

Taylor, B. and Martinez, F. 2003. Back arc basin basalt systematic. Earth and Planetary Science Letters 210, 481-497.

Tatsumi, Y. and Eggins, S. 1995. Subduction zone magmatism: Boston, Blackwell Science, 211 p.

Tomlinson, A., Cornejo, P., Mpodozis, C. 1999. Hoja Potrerillos, Región de Atacama, vol. 14. Servicio Nacional de Geología y Minería Mapa Geológico. Escala 1:100,000. Santiago.

Vásquez, P., Glodny, J., Franz, G., Frei, D., Romer, R. L. 2011. Early Mesozoic Plutonism of the Cordillera de la Costa $\left(34^{\circ}-37^{\circ} \mathrm{S}\right)$, Chile: Constraints on the Onset of the Andean Orogeny. Journal of Geology 119 , $2,159-184$

Vergara, M., Levi, B., Nystrom, J., Cancino, A., 1995. Jurassic and Early Cretaceous island arc volcanism, extension, and subsidence in the Coast Range of central Chile. Geological Society of America Bulletin $107,1427-1440$.

Vicente, J.C., Beaudoin, B., Chávez, A., León, T. 1982. La cuenca de Arequipa (Sur Perú) durante el Jurásico y Cretácico Inferior. V Congreso Latinoamericano de Geología, vol. 1 121-153.

Vicente, J.C. 2006. Dynamic Paleogeography of the Jurassic Andean Basin: pattern of regression and general considerations on main features. Revista de la Asociación Geológica Argentina 61, 408-437.

Welkner, D., Arévalo, C., Godoy, E. 2006. Geología del area Freirina-El Morado, Region de Atacama. Servicio Nacional de Geología y Minería. Carta Geológica de Chile, Serie Geología Basica No. 100. 1 mapa. Escala 1:100.000. Santiago

Wasserburg, G. J., Jacobsen, S. B., DePaolo, D. J., McCulloch, M. T., Wen, T. 1981. Precise determination of $\mathrm{Sm} / \mathrm{Nd}$ ratios, $\mathrm{Sm}$ and $\mathrm{Nd}$ isotopic abundances in standard solutions. Geochimica et Cosmochimica Acta 45, 2311-2323.

Workman, R.K. and Hart, S.R. 2005. Major and trace element composition of the depleted MORB mantle (DMM). Earth and Planetary Science Letters 231: 53-72.

\section{Figure Captions}

Figure 1. a) Simplified geological map of the studied area, showing the location of the studied units. QVB: Quebrada Vicuñita Beds. LF: Lagunillas Formation. LF*: Lagunillas Formation-like rocks assigned to other units. PF: Picudo Formation. AF: Algarrobal Formation. ASVC: Agua Salada Volcanic Complex. LNF: La Negra Formation. Sample PR-11-161 belongs to the Los Cuartitos Sequence, included by Martin et al. (1995) as part of the Jurassic back-arc. Samples with "*" have radiometric ages. Map modified after SERNAGEOMIN (2003). b) Schematic location of the back-arc basins (hatched areas) during the Jurassic between $24^{\circ} 30^{\prime}$ and $39^{\circ} 30^{\prime}$. Segmented line separates three principal geomorfological domains: Costal Cordillera (CC) to the west, Central Depression (CD) in 
the middle and Precordillera (PC) and High Andes (HA) to the east; modified after Vicente et al. (2006).

Figure 2. a) Total Alkalis versus silica classification diagram (TAS, Le Maitre et al., 1989) b) $\mathrm{Nb} / \mathrm{Y}$ versus $\mathrm{Zr} / \mathrm{Ti}$ classification diagram for altered volcanic rocks. Alkaline and subalkaline limits are after Rickwood (1989). Five samples of QVB in the TAS diagram are from Cornejo et al. (1993).

Figure 3. Major elements versus $\mathrm{SiO}_{2}$ content (anhydrous base) for volcanic rocks of the studied units in Chilean Precordillera and main Cordillera between 26 and $31^{\circ} \mathrm{S}$. Five samples of QVB are from Cornejo et al. 1993.

Figure 4. Primitive mantle-normalized trace elements patterns for volcanic rocks of the studied units in Chilean Precordillera and main Cordillera between 26 and $31^{\circ} \mathrm{S}$. Normalizing values are from Sun and McDonough (1989).

Figure 5. Chondrite-normalized Rare Earth elements (REE) patterns for volcanic rocks of the studied units in Chilean Precordillera and main Cordillera between 26 and $31^{\circ} \mathrm{S}$. Normalizing values are from Sun and McDonough (1989).

Figure 6. ${ }^{87} \mathrm{Sr} /{ }^{86} \mathrm{Sr}$ versus ${ }^{143} \mathrm{Nd} /{ }^{144} \mathrm{Nd}$ (and $\varepsilon \mathrm{Nd}$ ) diagram from samples of the studied units in Chilean Precordillera and main Cordillera between 26 and $31^{\circ}$ S. BSE: Bulk Silica Earth. Ages corrected for in situ decay at $150 \mathrm{Ma}$. Gray dashed line show isotopic composition of the Jurassic arc and dark gray line show high density ( $>95 \%)$ of analysis from Rogers and Hawkesworth (1989), Lucassen and Franz (1994), Lucassen et al. (2002); Kramer et al. (2005); Lucassen et al. (2006). MORB 150 is actual MORB corrected for in-situ decay.

Figure 7. $\mathrm{Pb}$ isotopic ratios for volcanic rocks of the studied units in Chilean Precordillera and main Cordillera between 26 and $31^{\circ} \mathrm{S}$. a) ${ }^{207} \mathrm{~Pb} /{ }^{204} \mathrm{~Pb}$ vs ${ }^{208} \mathrm{~Pb} /{ }^{204} \mathrm{~Pb}$ showing the Stacey and Kramer (1975) curve (SK) of common $\mathrm{Pb}$ growth for the average Earth. Northern Hemisphere Reference Line (NHRL) after Hart (1984), and compositional field of Jurassic Arc in Nothern Chile includes more than $90 \%$ of analysis after Kramer et al. (2005), Lucassen and Franz (1994) and Lucassen et al. (2006). Average Paleozoic Crust (Av. Pz Crust) after Lucassen et al. (2002). The 150-Ma isochron and the geochron were calculated following the procedures of Stacey and Kramer (1975) and Faure and Mesing (2005). b) Projection of the same rocks, reference lines and compositional fields as in a) on the ${ }^{208} \mathrm{~Pb} /{ }^{204} \mathrm{~Pb}$ vs ${ }^{206} \mathrm{~Pb} /{ }^{204} \mathrm{~Pb}$ variation diagram.

Figure 8. ${ }^{40} \mathrm{Ar} /{ }^{39} \mathrm{Ar}$ age spectra for hornblends from volcanic rocks of the studied units in Chilean Precordillera and main Cordillera between 26 and $31^{\circ} \mathrm{S}$ (laser and furnace heating). Plateau and integrated ages are given at the two sigma $(2 \sigma)$ confidence level. 
Figure 9. Concordia diagrams for: a) sample PR-11-193 b) sample PR-11-150 c) sample PR-11-143.

Figure 10. Discriminant diagrams for the studied rocks. a) Zr versus Y plot acording to MacLean and Barret (1993) showing a dominant calcalkaline trend for the studied rocks and a more transitional to tholeiitic afinities for the QVB rocks. $\mathrm{b}$ ) $\mathrm{Ta} / \mathrm{Yb}$ versus $\mathrm{Th} / \mathrm{Yb}$ diagram according to Pearce (1983). The studied samples plot mainly in two fields: Calcalkaline rocks with a mix of Subduction components and within plate mantle enrichment, and rock with clear within plate afinities. c) Tectonic setting discrimination diagram (Cabanis and Lecolle, 1989) for volcanic (basic- intermediate) rocks in the studied area. CA: calc-alkaline basalts; Thol: tholeiites; VAT: volcanic arc tholeiites; Cont: continental tholeiites. Arc Rock areas in dashed lines after Oliveros et al. 2007.

Figure 11. $(\mathrm{La} / \mathrm{Nb})_{\mathrm{N}}$ contents in the studied units. Gray area marks the mean values in the Jurassic Arc of Northern Chile after Pichowiak 1994, Kramer et al. 2005; Lucassen et al. 2006, Oliveros et al. 2007.

Figure 12. $\mathrm{Nb} / \mathrm{Yb}$ vs $\mathrm{TiO} 2$ and $\mathrm{Nb} / \mathrm{Yb}$ vs $\mathrm{Nb}$ diagrams for Jurassic - Lower Cretacoues arc and back-arc volcanic rocks in northern Chile with $\mathrm{SiO}_{2}$ content below 54\%, except for the AF. Trajectories with bars represent the Equilibrated Melting of Depleted (Workman and Hart, 2005) and Primitive (McDonough and Sun, 1995) Mantle. Lines with black circles represent Equilibrium Crystallization and lines with gray circles represent AFC process after DePaolo, (1981), the value in parenthesis is the $r$ factor in the proposed equation. Steps in crystallization model are 10\%. Dashed lines represent melting paths of hypothetical sources such as garnet lherzolite (?') or different mixtures of Primitive and Depleted Mantle (?). Data for the "Other Jurassic-Lower Cretaceous Arc rocks" are from Marschik and Fontboté, (2001); Kramer et al. (2005) and Oliveros et al. (2007). Gt: Garnet in the source. LC: Lower Continental Crust. MC: Middle Continental Crust and UC: Upper Continental Crust, after Rudnick and Gao, (2003).

Figure 13. Schematic configuration of the Andean margin during the Late Jurassic. 1Andean Jurassic Arc. 2- Late Jurassic Intrusives. 3- Retro arc volcanic chain represented by Picudo and Algarrobal formations. 4- Back-arc volcanism of the Lagunillas Formation. 5Inundated back arc area with sub marine volcanism represented by Quebrada Vicuñita Beds. 6- Red continental deposit of the Lagunillas Formation. studied by Oliveros et al. 2012. AOC: Altered oceanic crust.

\section{Table captions}

Table 1: Principal characteristics of the four studied units

Table 2: Investigated samples, coordinates, formation, litology and mineralogy 
Table 3: Main and trace element chemistry of Upper Jurassic back-arc volcanic rocks in the studied units (oxides in wt.\%, trace elements in ppm)

Table 4: $\mathrm{Sr}, \mathrm{Nd}$ and $\mathrm{Pb}$ isotopic composition of Upper Jurassic back-arc volcanic rocks in the studied units.

$\varepsilon N d$ values are calculated as deviations from a chondritic uniform reservoir in part per $10^{4}$, using present-day values of ${ }^{143} \mathrm{Nd} /{ }^{144} \mathrm{Nd}=0.512638$ and ${ }^{147} \mathrm{Sm} /{ }^{144} \mathrm{Nd}=0.1967$ (Wasserburg et al. 1981; Faure 1986). Ages of rocks are from an average estimated age of $150 \mathrm{My}$. 


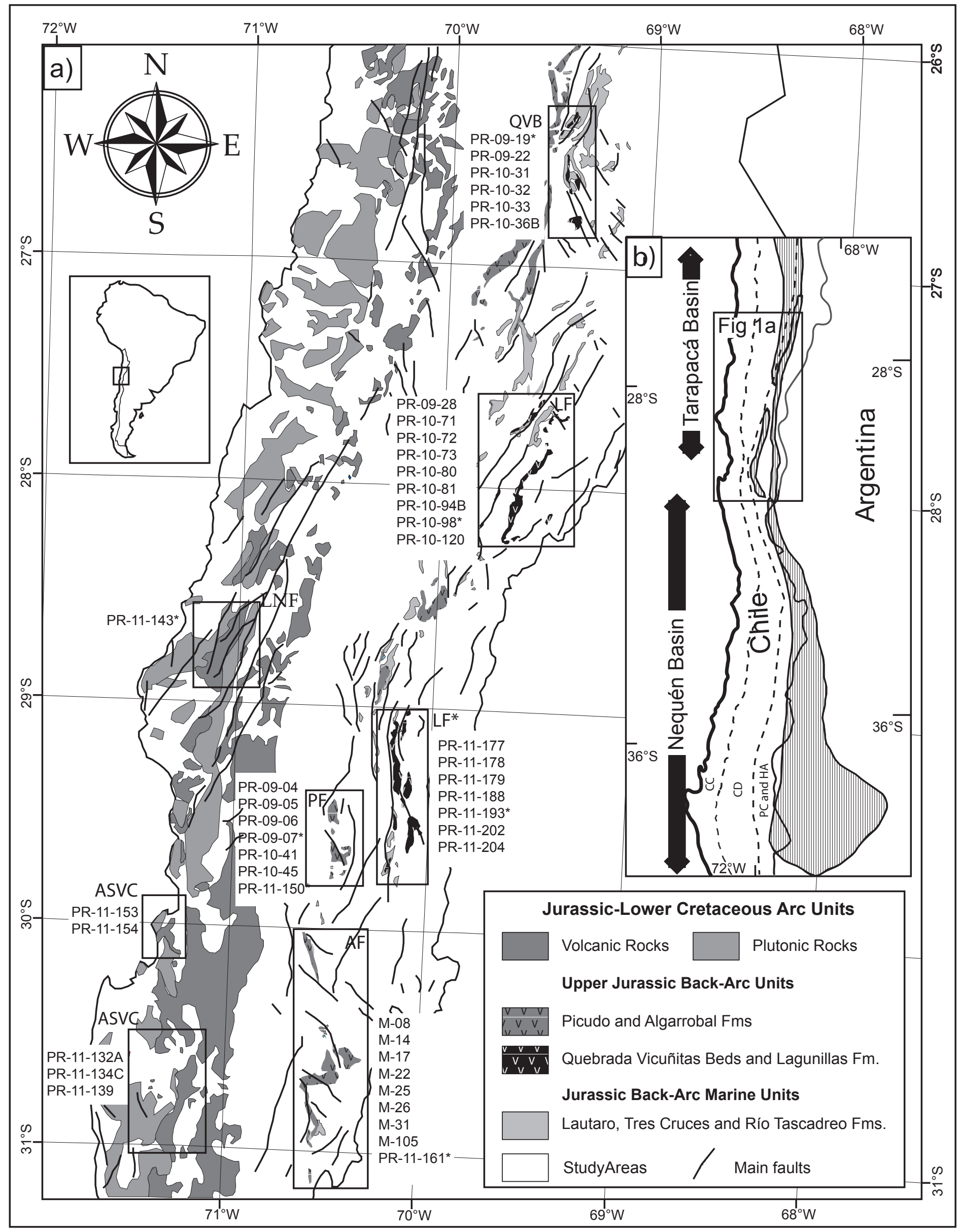




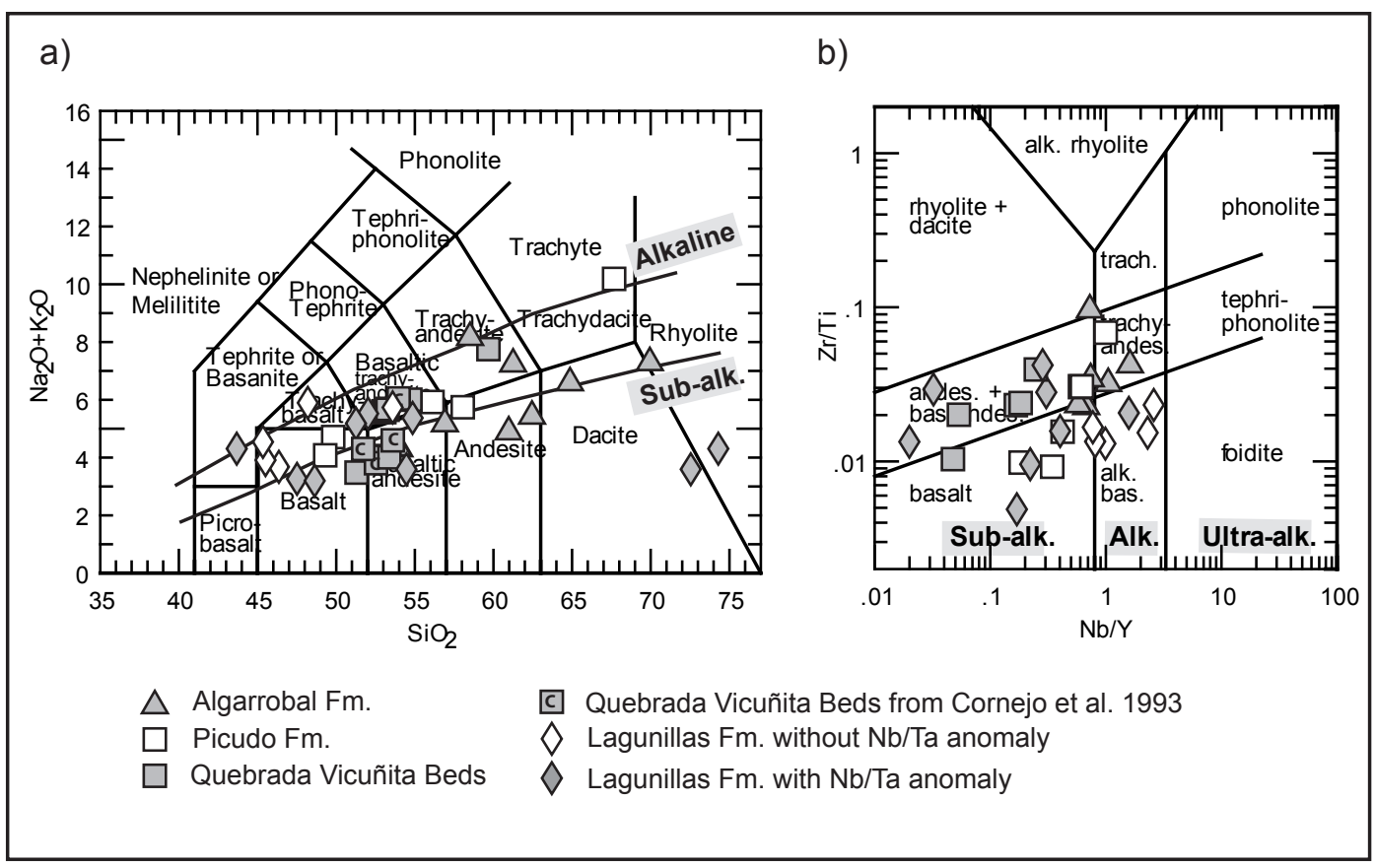




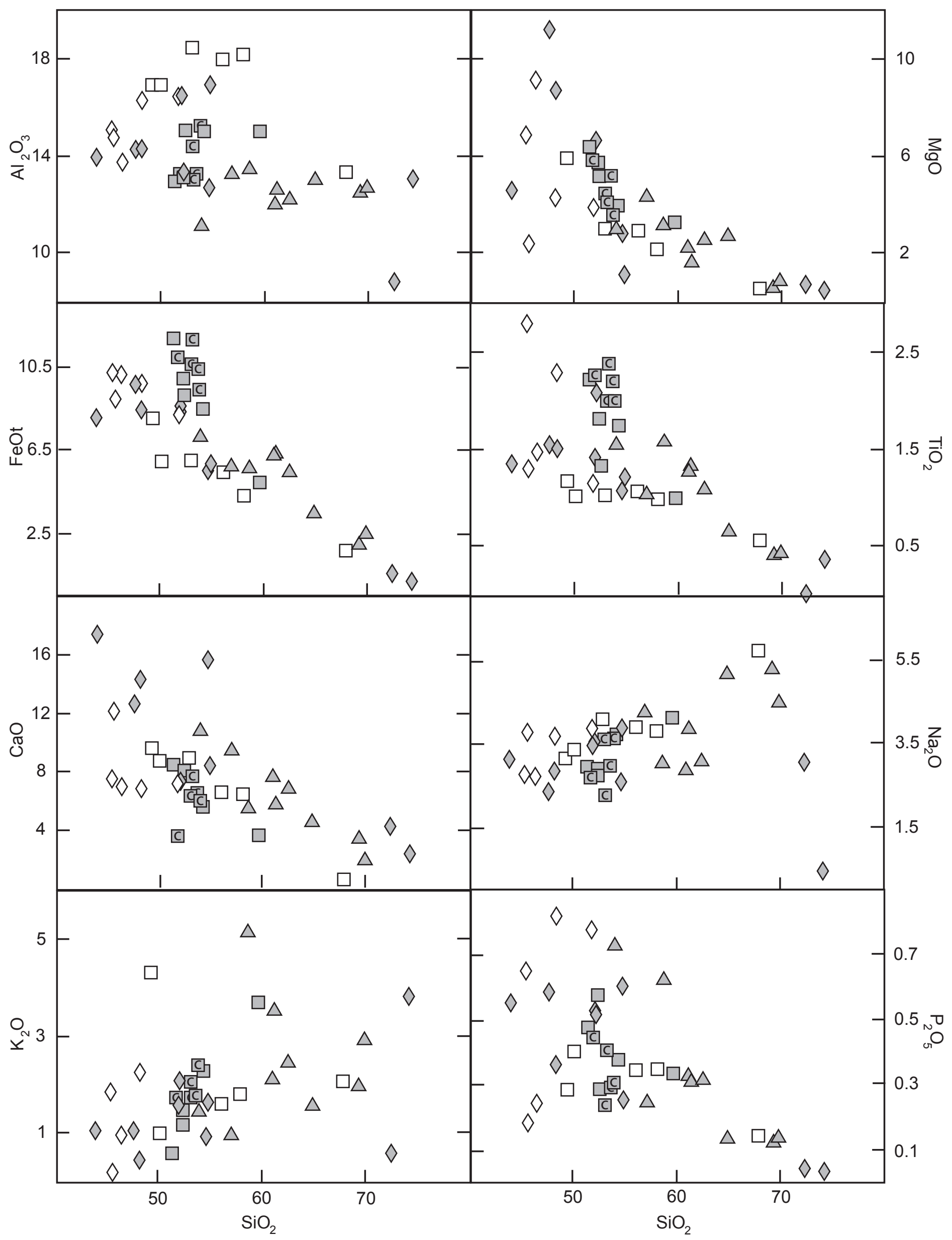
$\triangle$ Algarrobal Fm.
(c) Quebrada Vicuñita Beds from Cornejo et al. 1993
Picudo Fm.
$\diamond$ Lagunillas $\mathrm{Fm}$. without $\mathrm{Nb} / \mathrm{Ta}$ anomaly
Quebrada Vicuñita Beds
$\diamond$ Lagunillas $\mathrm{Fm}$. with $\mathrm{Nb} / \mathrm{Ta}$ anomaly 


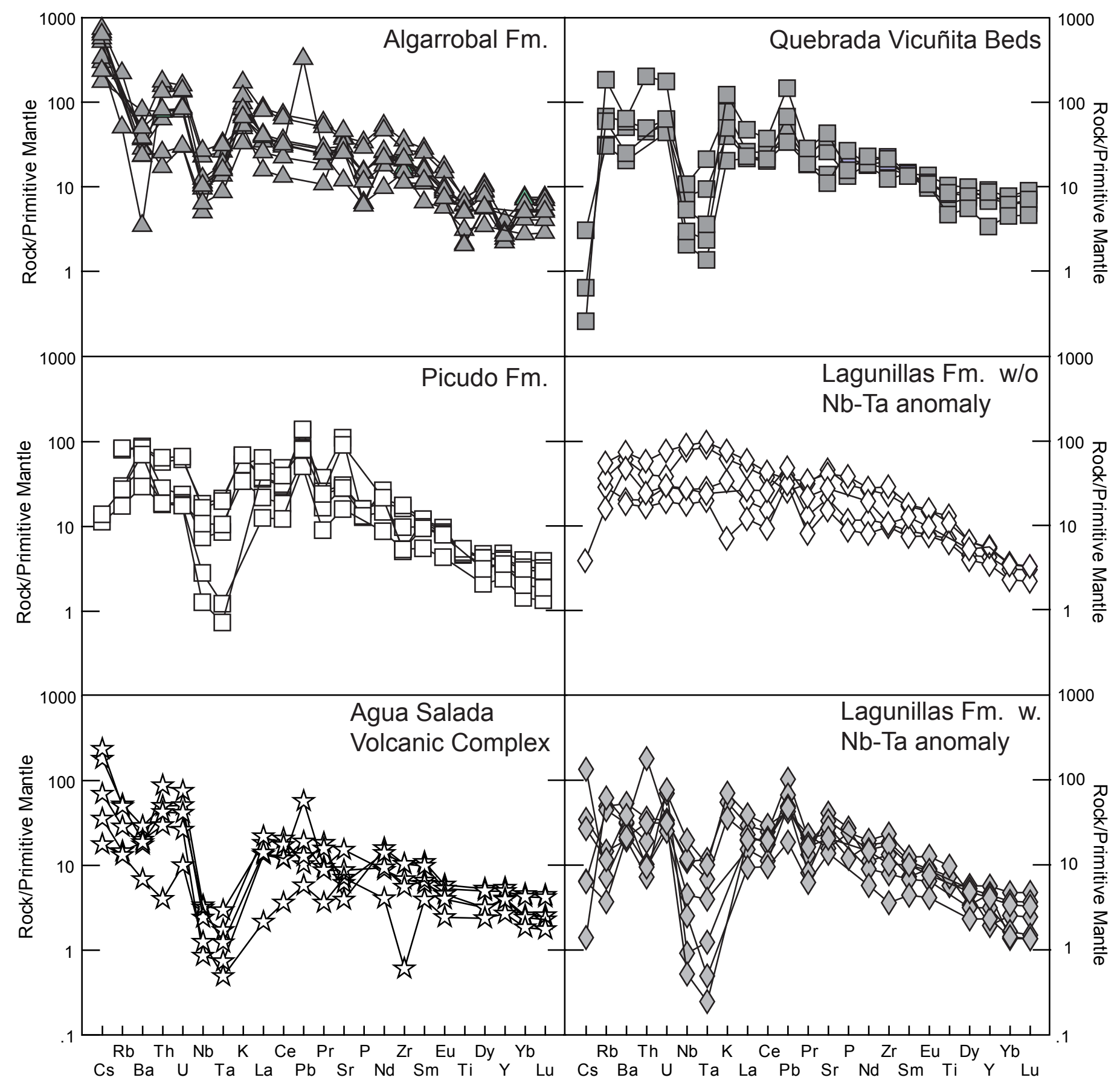




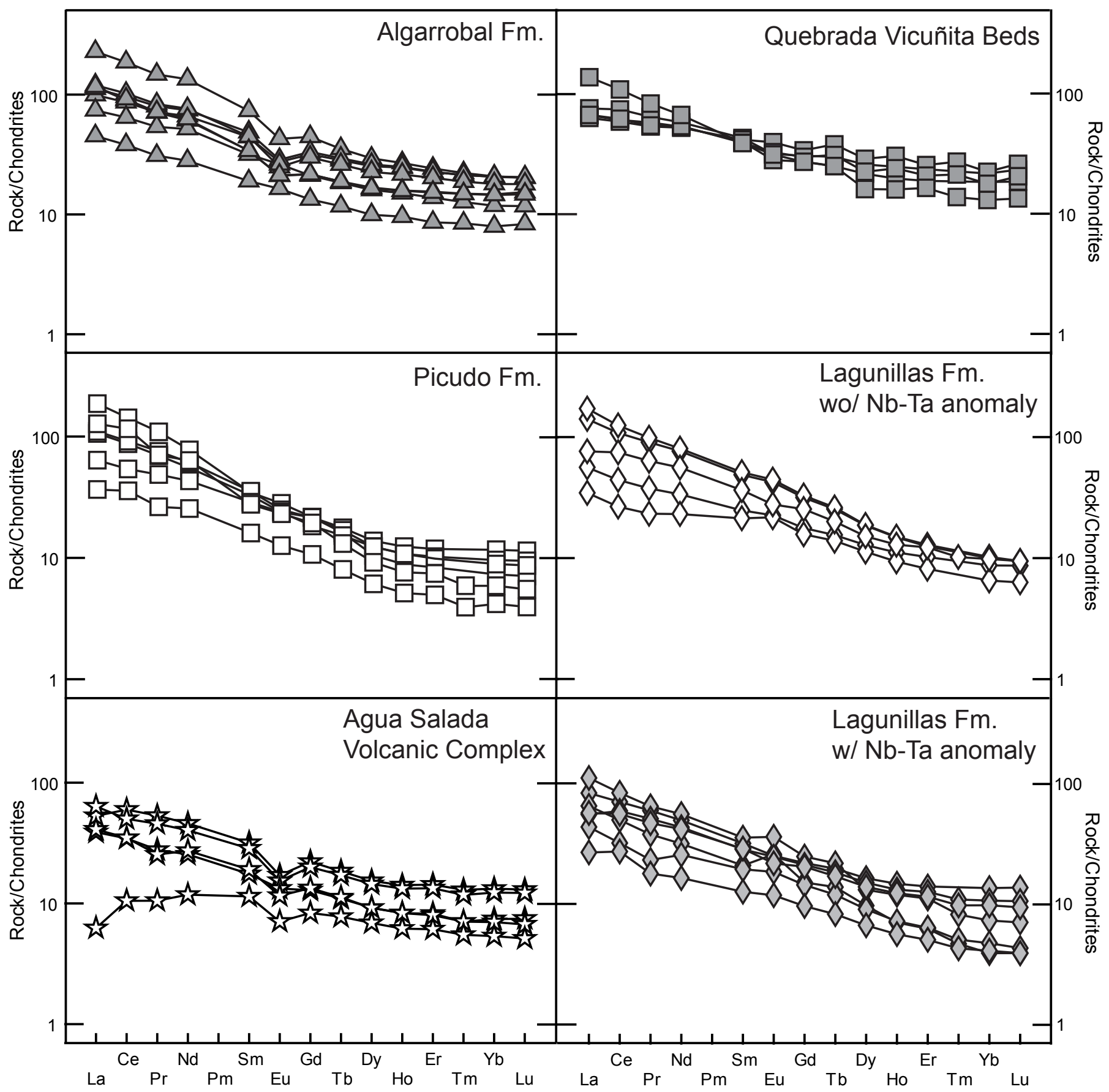




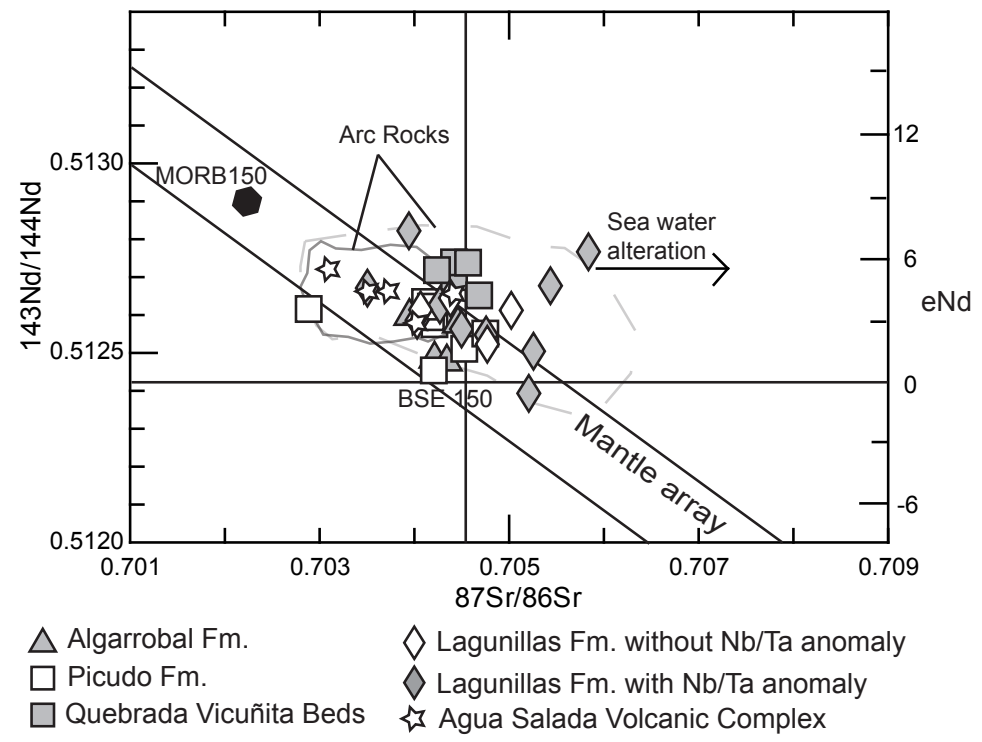




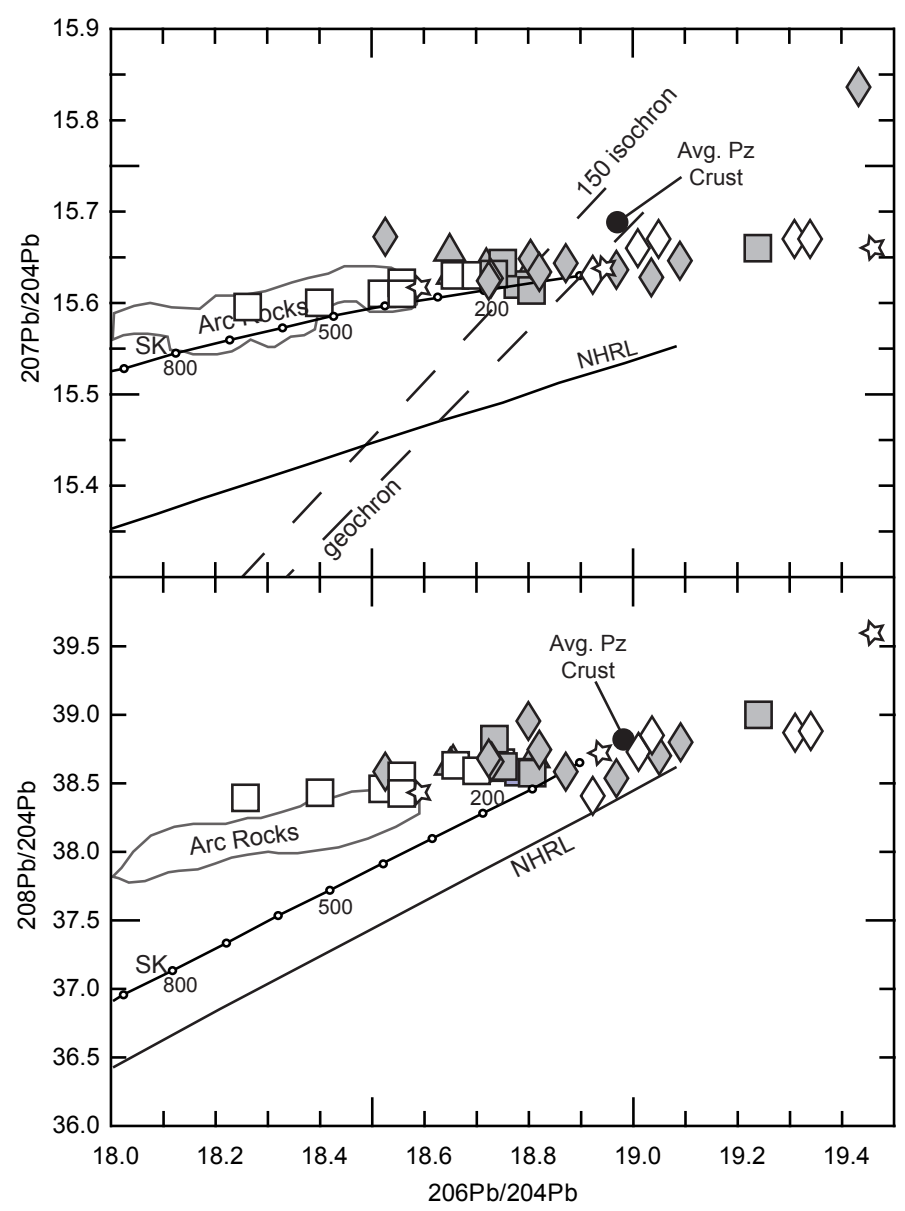

$\begin{array}{ll}\triangle \text { Algarrobal Fm. } & \diamond \text { Lagunillas } \mathrm{Fm} \text {. without } \mathrm{Nb} / \mathrm{Ta} \text { anomaly } \\ \square \text { Picudo Fm. } & \diamond \text { Lagunillas } \mathrm{Fm} \text {. with } \mathrm{Nb} / \mathrm{Ta} \text { anomaly }\end{array}$

$\square$ Quebrada Vicuñita Beds is Agua Salada Volcanic Complex 

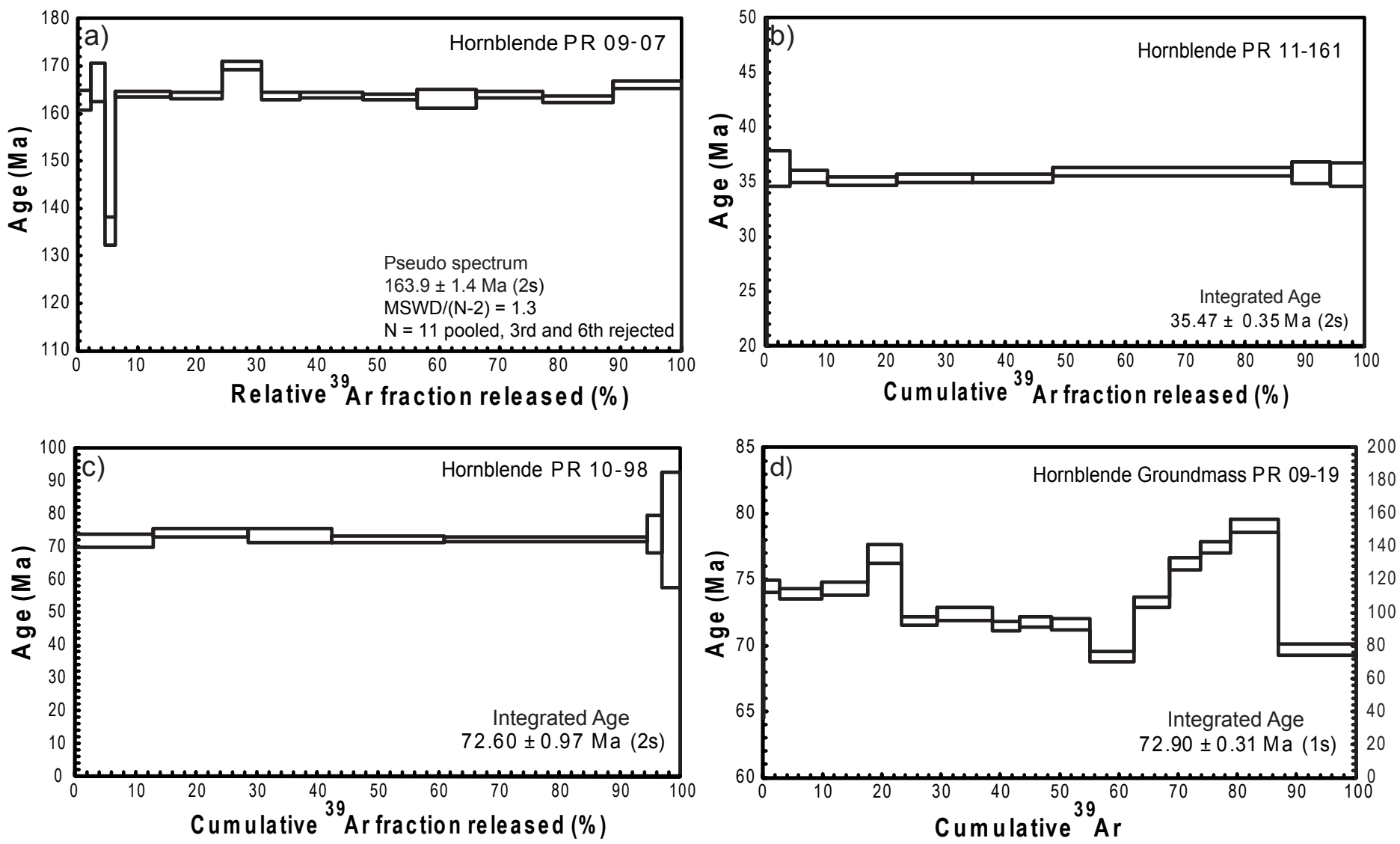

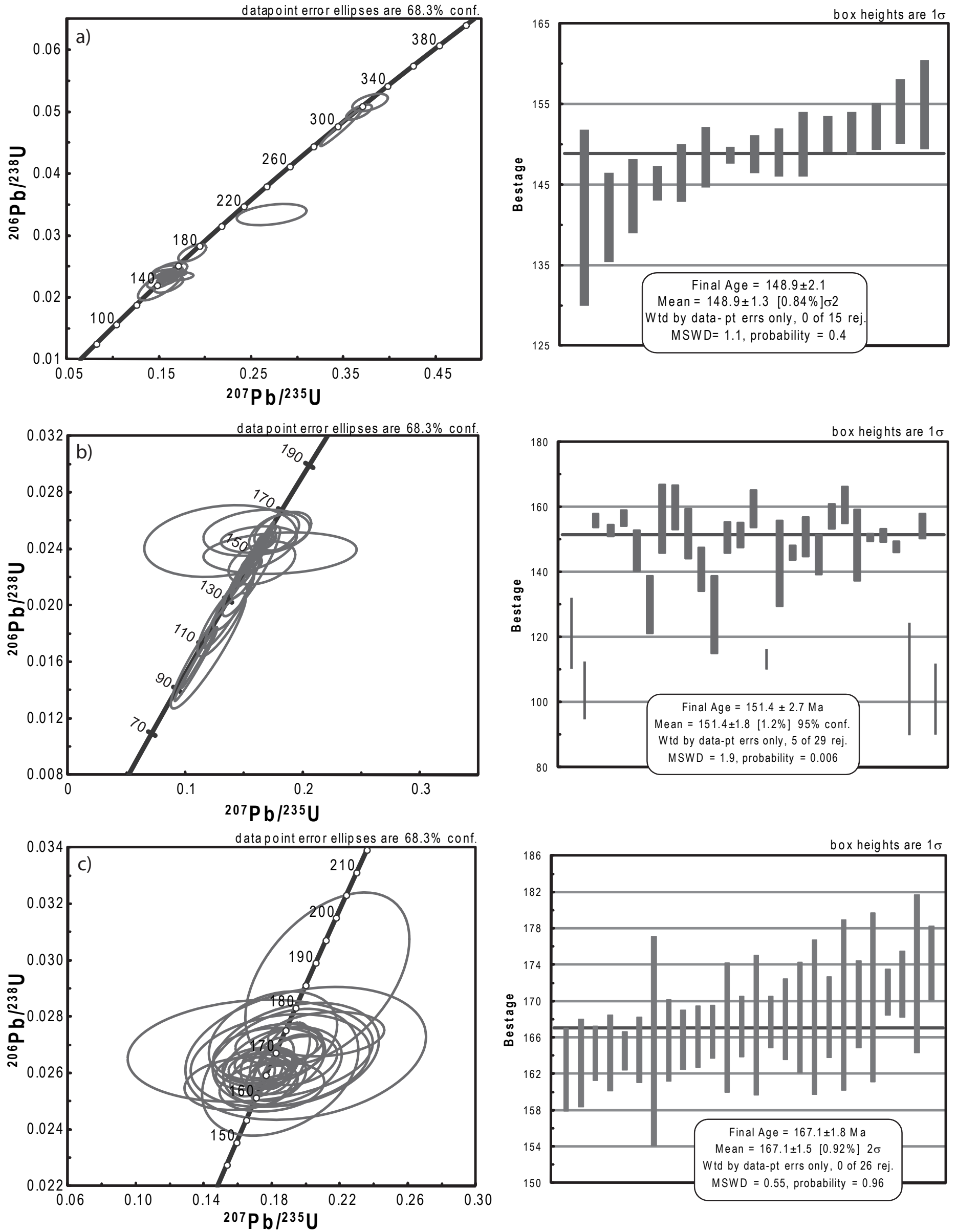

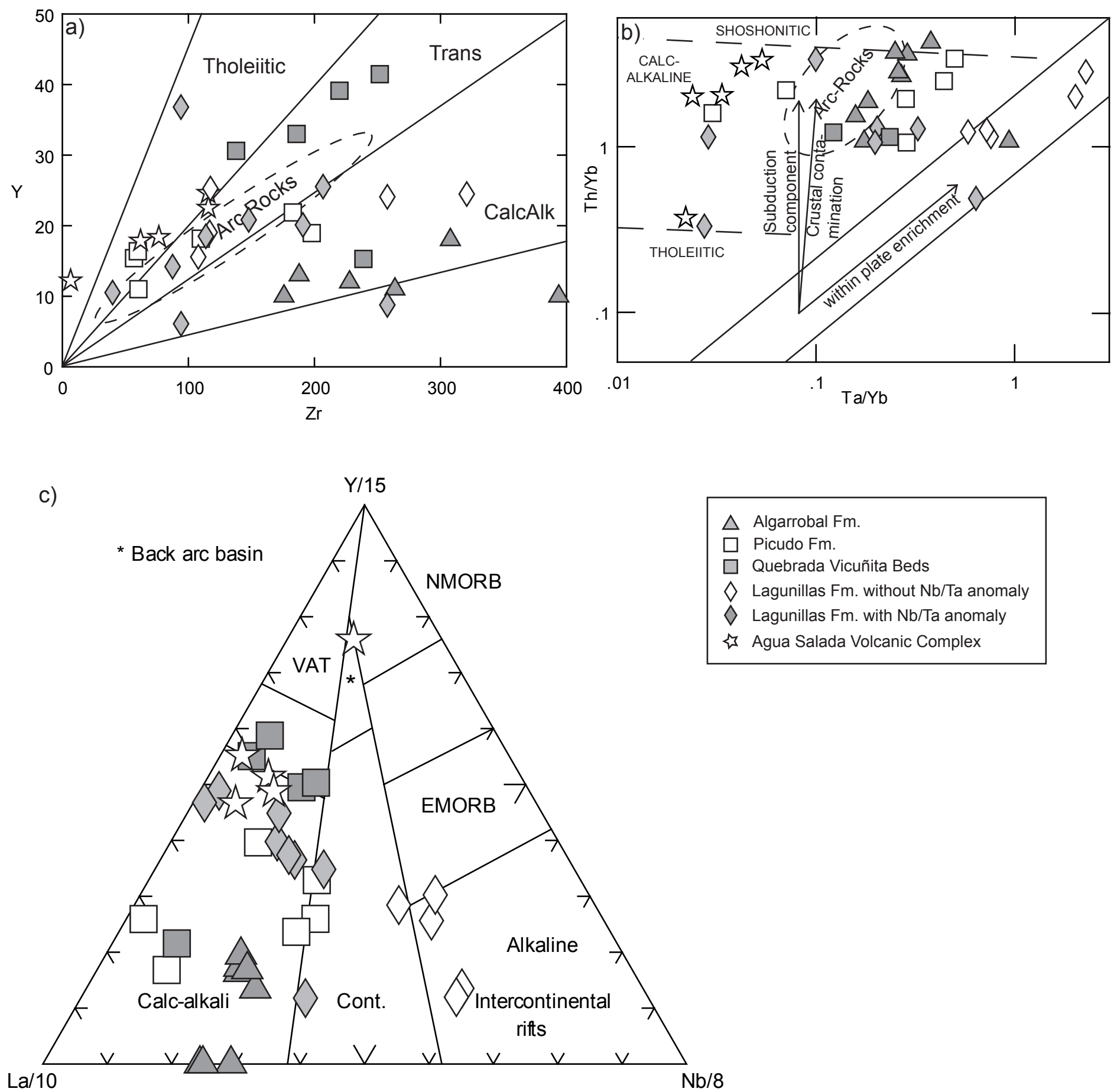

$\triangle$ Algarrobal Fm

$\square$ Picudo Fm.

$\square$ Quebrada Vicuñita Beds

$\diamond$ Lagunillas $\mathrm{Fm}$. without $\mathrm{Nb} / \mathrm{Ta}$ anomaly

$\diamond$ Lagunillas $\mathrm{Fm}$. with $\mathrm{Nb} / \mathrm{Ta}$ anomaly

is Agua Salada Volcanic Complex 


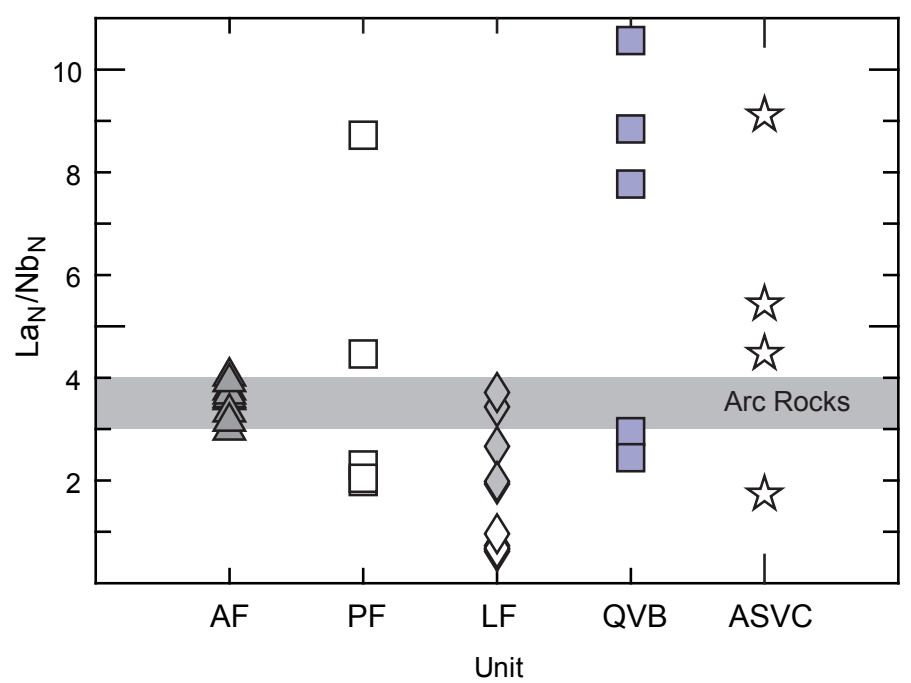

$\triangle$ Algarrobal Fm.

$\diamond$ Lagunillas $\mathrm{Fm}$. without $\mathrm{Nb} / \mathrm{Ta}$ anomaly $\square$ Picudo Fm.

$\diamond$ Lagunillas $\mathrm{Fm}$. with $\mathrm{Nb} / \mathrm{Ta}$ anomaly

$\square$ Quebrada Vicuñita Beds is Agua Salada Volcanic Complex 

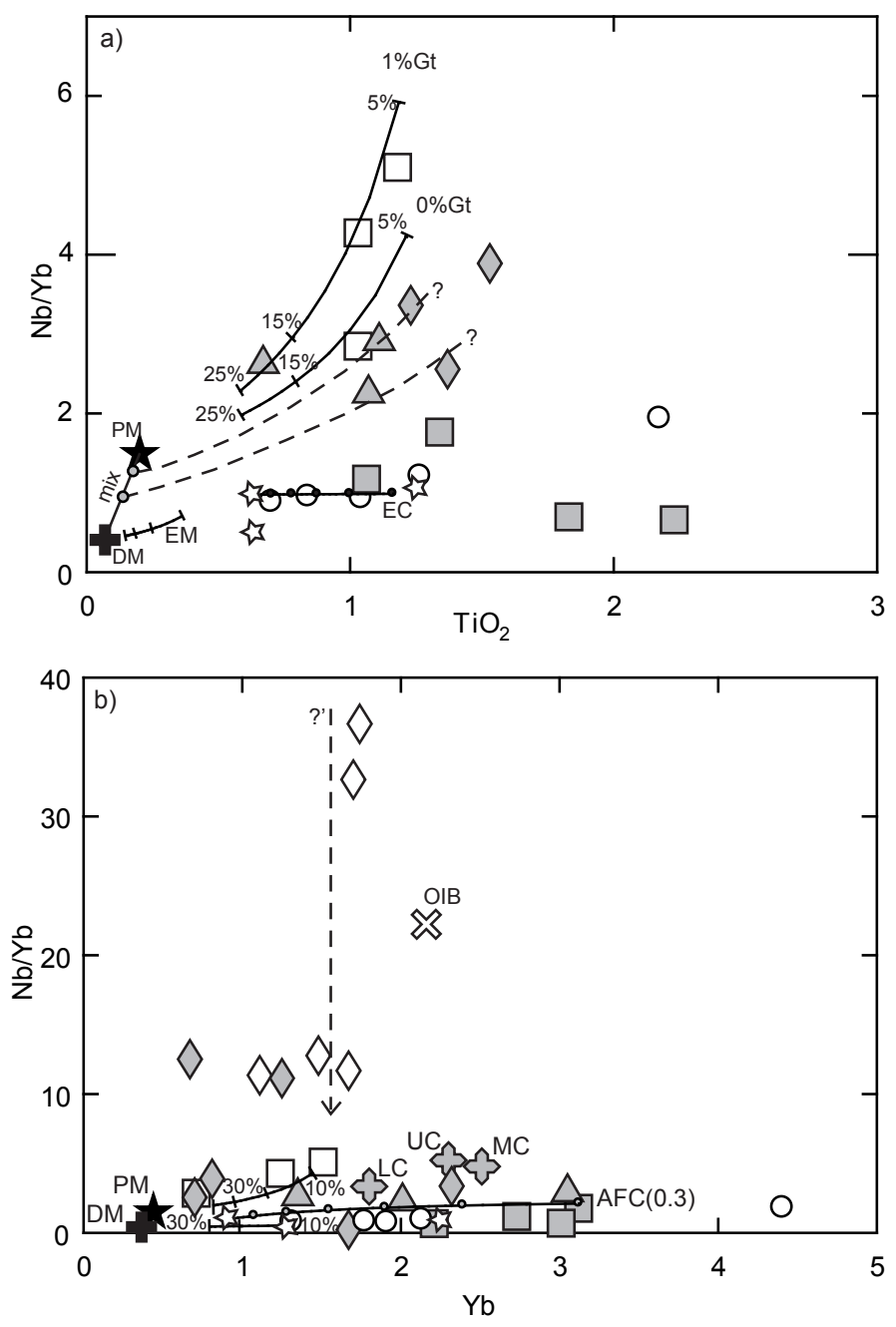
$\triangle$ Algarrobal Fm.
$\square$ Picudo Fm.
$\square$ Quebrada Vicuñita Beds
$\diamond$ Lagunillas $\mathrm{Fm}$. without $\mathrm{Nb} / \mathrm{Ta}$ anomaly
$\diamond$ Lagunillas $\mathrm{Fm}$. with $\mathrm{Nb} / \mathrm{Ta}$ anomaly
is Agua Salada Volcanic Complex
O Other Jurassic-Lower Cretaceous Arc rocks 


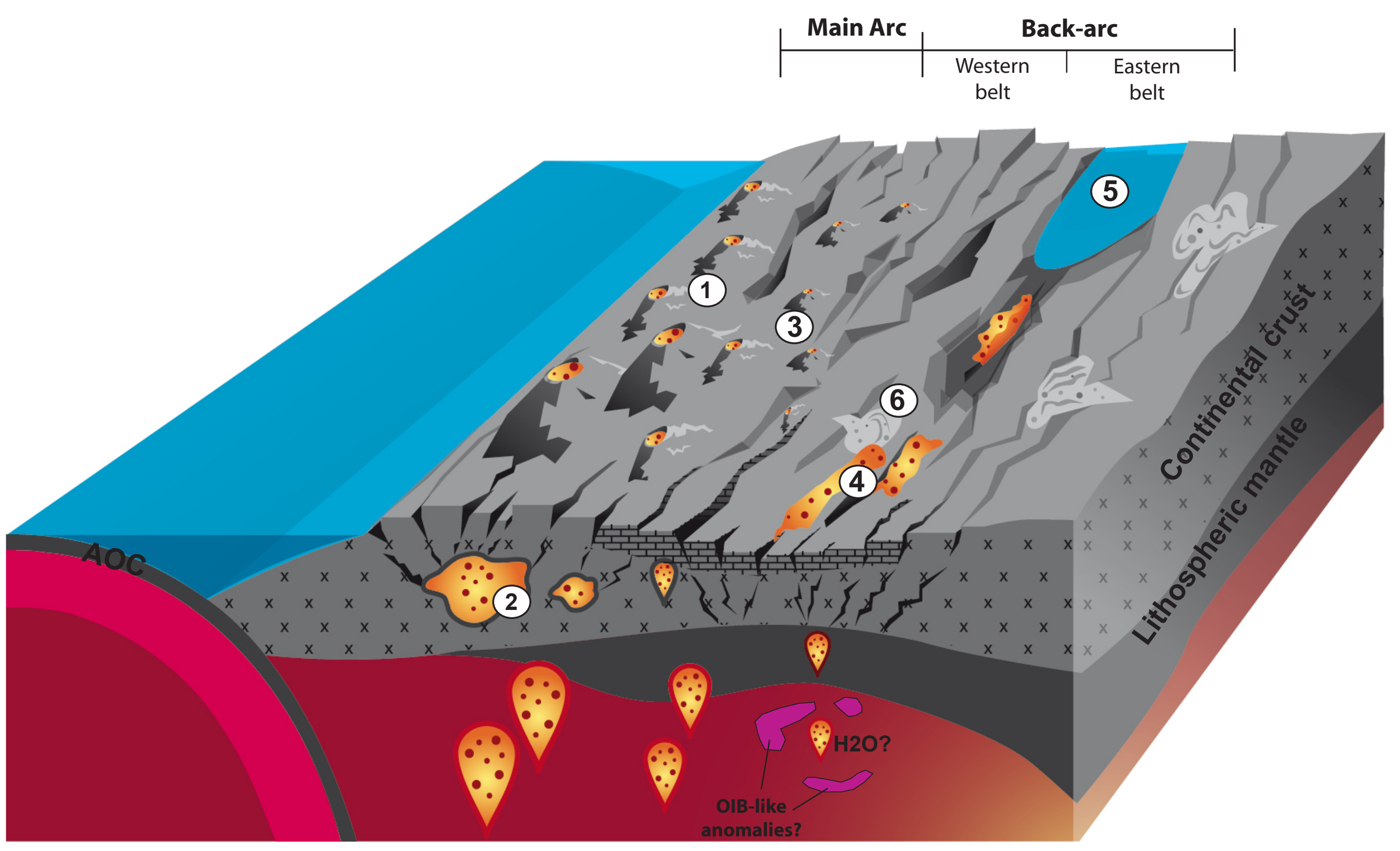


Table 1. Principal characteristics of the four studied units.

\begin{tabular}{|c|c|c|c|c|c|c|}
\hline Unit & $\begin{array}{c}\text { Geographic } \\
\text { position }\end{array}$ & $\begin{array}{c}\text { Stratigraphic } \\
\text { age }\end{array}$ & $\begin{array}{c}\text { Undelaying } \\
\text { unit }\end{array}$ & $\begin{array}{c}\text { Overlaying } \\
\text { unit }\end{array}$ & $\begin{array}{c}\text { Type/maximun } \\
\text { ticknes the of } \\
\text { volcanism }\end{array}$ & $\begin{array}{l}\text { Depositional } \\
\text { environmen }\end{array}$ \\
\hline $\begin{array}{l}\text { Quebrada } \\
\text { Vicunita } \\
\text { Beds }\end{array}$ & $\begin{array}{l}\text { Between } 26^{\circ} \\
\text { and } 27^{\circ} 45^{\prime} \mathrm{S} \text {. }\end{array}$ & $\begin{array}{l}\text { Post Calovian- } \\
\text { Pre Titonian }\end{array}$ & $\begin{array}{l}\text { Asientos } \\
\text { Formation }\end{array}$ & $\begin{array}{l}\text { Pedernales } \\
\text { Formation }\end{array}$ & Basic/200 m & Marine \\
\hline $\begin{array}{l}\text { Lagunillas } \\
\text { Formation }\end{array}$ & $\begin{array}{l}\text { Between } \\
27^{\circ} 20^{\prime} \text { and } \\
29^{\circ} 50^{\prime} \mathrm{S} \text {. }\end{array}$ & Upper Jurassic & $\begin{array}{l}\text { Lautaro } \\
\text { Formation }\end{array}$ & $\begin{array}{l}\text { Quebrada } \\
\text { Monardes } \\
\text { Formation }\end{array}$ & Basic/200 m & Continental \\
\hline $\begin{array}{l}\text { Picudo } \\
\text { Formation }\end{array}$ & $\begin{array}{l}\text { Between } \\
28^{\circ} 20^{\prime} \text { and } \\
29^{\circ} \mathrm{S}\end{array}$ & Upper Jurassic & $\begin{array}{l}\text { Lautaro } \\
\text { Formation }\end{array}$ & $\begin{array}{l}\text { Erotional } \\
\text { Surface }\end{array}$ & Bi-modal/500 m & Continental \\
\hline $\begin{array}{l}\text { Algarrobal } \\
\text { Formation }\end{array}$ & $\begin{array}{l}\text { Between } \\
29^{\prime} 30 \text { and } \\
31^{\circ} \mathrm{S}\end{array}$ & Upper Jurassic & $\begin{array}{l}\text { Tres Cruces } \\
\text { Formation }\end{array}$ & $\begin{array}{l}\text { Pucalume } \\
\text { Formation }\end{array}$ & Bi-modal/500 m & Continental \\
\hline
\end{tabular}


Table 2. Investigated samples, coordinates, formation, litology and mineralogy.

\section{Sample No. Coordinates Rock type Composition Mineralogy \\ Coordinates}

Estratos de Quebrada Vicuñita

\begin{tabular}{ll} 
PR-09-22 & 461080 \\
PR-10-31 & 461076 \\
PR-10-32 & 456968 \\
PR-10-33 & 456968 \\
PR-10-36B & 455289 \\
\hline Lagunillas & Formation \\
PR-09-28 & 435255 \\
PR-10-71 & 446046 \\
PR-10-72 & 446046 \\
PR-10-73 & 454759 \\
PR-10-80 & 444163 \\
PR-10-81 & 444163 \\
PR-10-94B & 437180 \\
PR-10-120 & 435255 \\
PR-11-177 & 411437 \\
PR-11-178 & 410376 \\
PR-11-179 & 405595 \\
PR-11-188 & 387212 \\
PR-11-193 & 405458 \\
PR-11-202 & 406490 \\
PR-11-204 & 406313 \\
\hline
\end{tabular}

Picudo Formation

$\begin{array}{ll}\text { PR-09-04 } & 375194 \\ \text { PR-09-05 } & 375402 \\ \text { PR-09-06 } & 375402 \\ \text { PR-09-07 } & 376364 \\ \text { PR-10-41 } & 374711 \\ \text { PR-10-42B } & 374711 \\ \text { PR-10-45 } & 373840 \\ \text { PR-11-150 } & 376364 \\ \text { PR-11-164 } & 374022 \\ \text { PR-11-168 } & 375288\end{array}$

6809854 Tuff

6796136 Lava flow

6796136 Lava flow

6797510

Breccia clast

6791142 Lava flow

6791142 Tuff

6791219 Lava flow

6797510 Tuff

6791021 Lava flow

6796083 Lava flow

Algarrobal Formation

$\begin{array}{ll}\text { M-8 } & 352114 \\ \text { M-14 } & 352250 \\ \text { M-15 } & 351524 \\ \text { M-17 } & 344947 \\ \text { M-22 } & 345226 \\ \text { M-25 } & 345541 \\ \text { M-26 } & 346065 \\ \text { M-31 } & 356350 \\ \text { M-105 } & 352114\end{array}$

6681849 Lava flow 6681573 Lava flow

6681623 Lava flow

6681470 Lava flow

6681372 Lava flow

6681123 Lava flow

6628180 Lava flow

6681849 Lava flow
6681451 Lava flow basaltic andesite plg, cpx, Fe-Ti oxides basaltic andesite plg, cpx, Fe-Ti oxides basaltic andesite plg, cpx, Fe-Ti oxides andesite plg, cpx, Fe-Ti oxides basalt plg, cpx, Fe-Ti oxides

basalt plg, cpx, ol, fe-ti oxides basalt plg, cpx, ol, fe-ti oxides basalt plg, cpx, ol, fe-ti oxides basalt plg, ol, fe-ti oxides basalt plg, cpx, ol, fe-ti oxides basaltic andesite plg, ol, fe-ti oxides basalt plg, ol, fe-ti oxides basaltic andesite plg, cpx, ol, fe-ti oxides basalt plg, ol dacite plg, glass, qz basalt plg, ol, Fe-Ti oxides basalt plg, cpx, ol dacite glass, qz, kspar, acid litics basalt plg, opx, ol basalt plg, cpx, ol

riolite glass, $\mathrm{qz}$ basaltic andesite plg, cpx, opx, Fe-Ti oxides basaltic andesite plg, cpx, Fe-Ti oxides andesite plg, cpx, hbl, fe-ti oxides basaltic andesite plg, cpx, Fe-Ti oxides dacite tuff fragments, qz, fe-ti oxides basalt plg, cpx, ol, fe-ti oxides dacite tuff fragments, qz, fe-ti oxides basaltic andesite plg, cpx, ol, fe-ti oxides andesite plg, cpx, fe-ti oxides

dacite plg, px, qz, fe-ti oxides basaltic andesite plg, cpx, ol, fe-ti oxides andesite plg, fe-ti oxides andesite plg, cpx, opx, Fe-Ti oxides andesite plg, cpx, opx, Fe-Ti oxides andesite plg, cpx, opx, Fe-Ti oxides dacite plg, cpx, opx, Fe-Ti oxides basaltic andesite plg, cpx, ol, fe-ti oxides dacite plg, fe-ti oxides 
Sample No. Coordinates Rock type Composition Mineralogy

Coordinates

PR-11-132A 279051

6578873 Lava flow

basaltic andesite plg, cpx, fe-ti oxides 


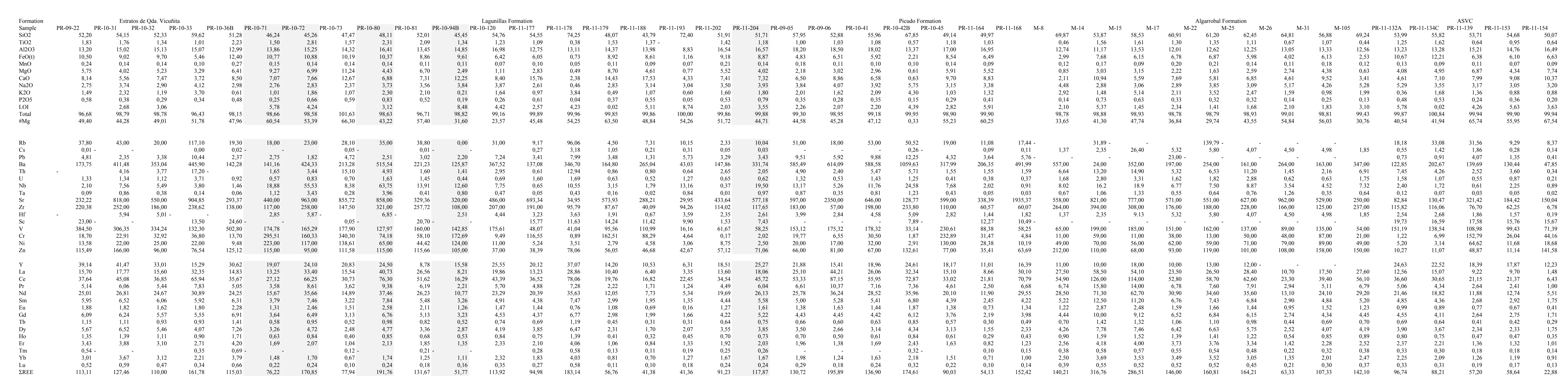




\begin{tabular}{|c|c|c|c|c|}
\hline \multirow{2}{*}{\multicolumn{2}{|c|}{$\begin{array}{l}\text { Sample No. Coordin } \\
\text { Estratos de Quebrada Vicuñita }\end{array}$}} & \multirow[t]{2}{*}{ Rock type } & \multirow[t]{2}{*}{ Composition } & \multirow[t]{2}{*}{ Mineralogy } \\
\hline & & & & \\
\hline PR-09-22 & 461080 & 7032910 Lava flow & basaltic andesite & plg, cpx, Fe-Ti oxides \\
\hline PR-10-31 & 461076 & 7080490 Lava flow & basaltic andesite & plg, cpx, Fe-Ti oxides \\
\hline PR-10-32 & 456968 & 7085732 Lava flow & basaltic andesite & plg, cpx, Fe-Ti oxides \\
\hline PR-10-33 & 456968 & 7085732 Lava flow & andesite & plg, cpx, Fe-Ti oxides \\
\hline PR-10-36B & 455289 & 7083200 Lava flow & basalt & plg, cpx, Fe-Ti oxides \\
\hline \multicolumn{5}{|c|}{ Lagunillas Formation } \\
\hline PR-09-28 & 435255 & 6888075 Lava flow & basalt & plg, cpx, ol, Fe-Ti oxides \\
\hline PR-10-71 & 446046 & 6935452 Lava flow & basalt & plg, cpx, ol, Fe-Ti oxides \\
\hline PR-10-72 & 446046 & 6935452 Lava flow & basalt & plg, cpx, ol, Fe-Ti oxides \\
\hline PR-10-73 & 454759 & 6951846 Lava flow & basalt & plg, ol, Fe-Ti oxides \\
\hline PR-10-80 & 444163 & 6929847 Lava flow & basalt & plg, cpx, ol, Fe-Ti oxides \\
\hline PR-10-81 & 444163 & 6929847 Lava flow & basaltic andesite & plg, ol, Fe-Ti oxides \\
\hline PR-10-94B & 437180 & 6887765 Lava flow & basalt & plg, ol, Fe-Ti oxides \\
\hline PR-10-120 & 435255 & 6888075 Lava flow & basaltic andesite & plg, cpx, ol, Fe-Ti oxides \\
\hline PR-11-177 & 411437 & 6837465 Lava flow & basalt & plg, ol \\
\hline PR-11-178 & 410376 & 6835416 Tuff & dacite & plg, glass, qz \\
\hline PR-11-179 & 405595 & 6834032 Lava flow & basalt & plg, ol, Fe-Ti oxides \\
\hline PR-11-188 & 387212 & 6776305 Lava flow & basalt & plg, cpx, ol \\
\hline PR-11-193 & 405458 & 6833701 Dacite & dacite & glass, qz, kspar. \\
\hline PR-11-202 & 406490 & 6834927 Lava flow & basalt & plg, opx, ol \\
\hline PR-11-204 & 406313 & 6834588 Lava flow & basalt & plg, cpx, ol \\
\hline \multicolumn{5}{|c|}{ Picudo Formation } \\
\hline PR-09-04 & 375194 & 6809854 Tuff & riolite & glass, qz \\
\hline PR-09-05 & 375402 & 6796136 Lava flow & basaltic andesite & plg, cpx, opx, Fe-Ti oxides \\
\hline PR-09-06 & 375402 & 6796136 Lava flow & basaltic andesite & plg, cpx, Fe-Ti oxides \\
\hline PR-09-07 & 376364 & 6797510 Brechia clast & andesite & plg, cpx, hbl, Fe-Ti oxides \\
\hline PR-10-41 & 374711 & 6791142 Lava flow & basaltic andesite & plg, cpx, Fe-Ti oxides \\
\hline PR-10-42B & 374711 & 6791142 Tuff & dacite & tuff fragments, qz, Fe-Ti oxides \\
\hline PR-10-45 & 373840 & 6791219 Lava flow & basalt & plg, cpx, ol, Fe-Ti oxides \\
\hline PR-11-150 & 376364 & 6797510 Tuff & dacite & tuff fragments, qz, Fe-Ti oxides \\
\hline PR-11-164 & 374022 & 6791021 Lava flow & basaltic andesite & plg, cpx, ol, Fe-Ti oxides \\
\hline PR-11-168 & 375288 & 6796083 Lava flow & andesite & plg, cpx, Fe-Ti oxides \\
\hline \multicolumn{5}{|c|}{ Algarrobal Formation } \\
\hline M-8 & 352114 & 6681849 Lava flow & dacite & plg, px, qz, Fe-Ti oxides \\
\hline M-14 & 352250 & 6681573 Lava flow & basaltic andesite & plg, cpx, ol, Fe-Ti oxides \\
\hline M-15 & 351524 & 6681623 Lava flow & andesite & plg, Fe-Ti oxides \\
\hline M-17 & 344947 & 6681470 Lava flow & andesite & plg, cpx, opx, Fe-Ti oxides \\
\hline M-22 & 345226 & 6681451 Lava flow & andesite & plg, cpx, opx, Fe-Ti oxides \\
\hline M-25 & 345541 & 6681372 Lava flow & andesite & plg, cpx, opx, Fe-Ti oxides \\
\hline M-26 & 346065 & 6681123 Lava flow & dacite & plg, cpx, opx, Fe-Ti oxides \\
\hline M-31 & 356350 & 6628180 Lava flow & basaltic andesite & plg, cpx, ol, Fe-Ti oxides \\
\hline M-105 & 352114 & 6681849 Lava flow & dacite & plg, Fe-Ti oxides \\
\hline \multicolumn{5}{|c|}{ Complejo Volcanico Agua Salada } \\
\hline PR-11-132A & 279051 & 6578873 Lava flow & basaltic andesite & plg, cpx, Fe-Ti oxides \\
\hline PR-11-134C & 277380 & 6576545 Lava flow & basaltic andesite & plg, cpx, Fe-Ti oxides \\
\hline PR-11-139 & 276373 & 6615346 Lava flow & basaltic andesite & plg, cpx, Fe-Ti oxides \\
\hline
\end{tabular}




$\begin{array}{lrlll}\begin{array}{l}\text { PR-11-153 } \\ \text { PR-11-154 }\end{array} & 275629 & \text { 6729590 Subvolcanic intrusive } & \text { basaltic andesite } \\ \text { La Negra Formation } & 278965 & 6724231 \text { Subvolcanic intrusive } & \text { pasalt } & \text { plg, cpx, Fe-Ti oxides } \\ \text { PR-11-143 } & 290206 & 6862894 \text { Tuff } & \text { andesitic } & \text { qz, plg, lithic fragments } \\ \begin{array}{l}\text { Other Samples } \\ \text { PR-10-98 }\end{array} & 451710 & 6904323 \text { Tuff } & \text { dacitic } & \text { qz, plg, hbl, acid litics } \\ \text { PR-11-161 } & 396843 & 6677577 \text { Tuff } & \text { dacitic } & \text { qz, plg, hbl, acid litics }\end{array}$

